\title{
CODIFIERS OF THE CRIMINAL LAW:
}

\section{WECHSLER'S PREDECESSORS}

\author{
SANFORD H. KADISH *
}

Two of my vivid memories of Columbia Law School in the long, hot summer of 1946 are connected. One was the air-conditioned auditorium of Butler Library; the other the class in Criminal Law that Herbert Wechsler taught there. Professor Wechsler's class stirred in me an admiration for the academic legal mind at its best and an engrossment with the substantive criminal law that inparted permanent shape and direction to my subsequent legal career. A behaviorist would say it was the air-conditioning. I know better. Relief from the heat was the condition, Professor Wechsler the cause. After all, Property-though equally air-cooled-never laid a glove on me. For these personal reasons, therefore, as well as because Herbert Wechsler stands im my generation as a towering figure who, more than anyone else, made the study of criminal law a respectable intellectual enterprise once again, contributing to this celebratory issue is an act of homage (though without, I hasten to say, the reciprocal expectation of protection that once went with it).

For this essay I have chosen a subject suggested by one of Wechsler's spectacular achievements, the Model Penal Code, for which he was Chief Reporter and guiding spirit. In that role he was the latest $m$ a tradition of Anglo-American criminal law codifiers going back to Jeremy Benthain, who launched the nineteenth-century codification movement in the Enghishspeaking jurisdictions of the world. There were many who contributed significantly in one way or another to statutory reform-people like Romilly, Broughain, Peel, and Greaves. ${ }^{1}$ But I have in mind those few figures, of whoin Wechsler is the pre-eminent twentieth-century representative, who produced original, comprehensive codes of criminal law $\mathrm{m}$ the Benthamite style-Edward Livingston in Louisiana; Thomas Babington Macaulay in India; David Dudley Field in New York; and Sir James Fitzjames Stephen in England. In the following pages I propose to sketch something of the circumstances of their codification efforts, the spirit that motivated these Inen, the philosophy and outlook they brought to the task, the character of the codes they produced, and the significance of their work.

* Dean and Morrison Professor of Law, University of California, Berkeley. B.S.S. 1942, City College of New York; LL.B. 1948, Columbia University. I owe thanks to Charles R. Myers, J.D. 1978, University of California, Berkeley, and to Alice Youmans, Associate Reference Law Librarian, University of California, Berkeley, J.D. 1975, University of California, Hastings, for their research and bibliographic lielp, respectively.

1. For a review of the importance of several earlier criminal law writers, see Ashworth, The Making of English Criminal Law, (4) Blackstone, Foster and East, 1978 Crum. L.R. 389 
A word, first, about Bentham. Though in a sense the greatest codifier of all, he was, in the end, a codifier manqué. While he wrote far and wide to obtain a codification commission-to the English Home Secretary, ${ }^{2}$ to President Madison (twice), ${ }^{3}$ to the Governor of Pennsylvania, ${ }^{4}$ to all the American governors ${ }^{5}$ and to the Russian Emperor ${ }^{6}$-he never obtained one; nor did he ever produce a completed code, penal or otherwise (which might have been just as well, to judge from the specimen of part of a penal code he did leave behind). ${ }^{7}$ What he did contribute to the movement for codification, however, was nothing less than its intellectual energy and content. $\mathrm{He}$ devoted much of his life to writing detailed plans for a variety of codes in the course of which he opened new fields of philosophical, moral, and legal inquiry. Moreover, he created a distinctive style of codification-codes drafted by learned "philosophes," reinoved froin the political process, proceeding systematically froin basic principle to practical corollary to the construction of an internally harmonious and philosophically grounded system-and left a deposit of thought that made him the intellectual father of codification generally and of penal codification in particular. ${ }^{8}$ Still, simce it is not Benthain but his code-writing epigone who are the subject of this essay, the force and content of his thinking may be more appropriately noted in the course of reviewing their work.

\section{EDWARD LIVINGSTON}

Edward Livingston, the draftsman of the proposed Louisiana Penal Code, was nearest in time and spirit to the Benthamite revolution in thought. A lawyer learned enough to meet the Benthamite standard-he was versed in French and Roman law, as well as in the common law ${ }^{9}$-he was also a man of affairs before, during, and after his penal code efforts, a characteris-

2. 10 WORKS OF JEREMY BENTHAM 469 (Bowring ed. 1843) [hereinafter cited as BeNTHAM WORKS].

3. J. Bentham, Papers Relative to Codification and Public Instruction, in 4 Bentram Works, supra note 2 , at $453,507$.

4. $I d$. at 468.

5. Id. at 476 .

6. Id. at 514 .

7. J. Bentram, Specimen of a Penal Code, in 1 Bentham Works, supra note 2, at 164. See also Jolowicz, Was Bentham a Lawyer?, in JEREMY BENTHAM AND THE LAW 1, 11-12 (G.W. Keeton \& G. Schwarzenberger eds. 1948).

8. Lord Bryce attributed the legal and governmental reforms in the last two-thirds of the nineteenth century to several factors, the first being "the general enlightenment of mind due to the play of spcculative thought upon practical questions which marked the end of the last and beginning of this [the 19th] century, and of which the most conspicuous apostles were Adam Smith in the sphere of economics and Jereiny Bentham in the sphere of legal reform." $2 \mathrm{~J}$. BRYCe, Studies IN History aNd JuRISpRUdence 768 (1901). See generally C. PhILIIPSON, Threb Criminal law Reformers ch. IV (1923); 1 L. Radzinowicz, A History of ENGLish Crmmal LAW 355-96 (1948); Alfange, Jeremy Bentham and the Codification of Law, 55 CORNELL L. Rev. 58 (1969); Holdsworth, Bentham's Place in English Legal History, 28 CALIF. L. REY. 568 (1940).

9. For a discussion of his background, see Moore, The Livingston Code, 19 J. AM. INST. CRIM. L. \& CrImINology 344, 346-47 (1928). Moore's bibliography of writings by and about Livingston is the most exhaustive one to come to my attention. Id. at 363 . 
tic shared in varying degrees by each of our codifiers and one whose significance for reform apparently escaped the cloistered Bentham. ${ }^{10}$ Before noving to Louisiana, he served as Congressman, U.S. Attorney, and Mayor of New York. In Louisiana he became a state legislator (where he engineered the act providing for the appointment of a person "learned in the law" to prepare a criminal code ${ }^{11}$ ), United States Congressman, and Senator; later he served as Secretary of State and Minister to Firance in Jackson's administration. ${ }^{12}$

Livingston was a reader and admirer of the works of Bentham that Dumont's labors had made available in French. ${ }^{13} \mathrm{He}$ embraced quite totally the utilitarian philosophy and its commitment to codification of the law. ${ }^{14}$ His law reform efforts began early. As a Congressman froin New York he had a committee appointed, which he later chaired, to explore the revision of the United States penal laws. ${ }^{15}$ In Louisiana he was involved in drafting not only a Penal Code, but also a Civil Code and a Code of Practice, both of which were successfully enacted, as well as a Commercial Code.10 His Penal Code, though never enacted, was his most significant achievement, representing the first conplete view of what a penal code built on Benthamite principles would look like. ${ }^{17}$

Livingston was preoccupied not just with the reform of the criminal law, but rather with the goal of comprehensive codification of all law that followed froin the general Benthamite philosophy, which he shared. According to this view, government had a proper role in shaping society and its institutions in accordance with the master primciple of utility. Precedent and tradition were never good reasons for a law; all law should be reappraised in hight of contemporary judgments founded on the science of legislation. ${ }^{18}$ Unclear, uusettled, and discordant laws were a needless curse.

10. See the comment on Bentham in Sir John Romilly's letter to Dumont in 1791: "Bentham leads the same kind of life as usual at Hendon,- - seeing nobody, reading nothing, and writing books which nobody reads." J. Dilion, THe Laws aNd JURISPRUDENCE or ENaLAND AND AMERICA 327 n.1 (1895). See also id. at 330 n.1.

11. 1 Complete Works of EdWard Livingston on CrRminat Jurisprudence 1 (1873) [hereinafter cited as Livingston Works]; W.B. HATCHER, EdWard LIVINGSTON 237 (1940).

12. See W. B. HATCHER, supra note 11; C.H. HUNT, LlFE op EdWARD Lrvingston (1864).

13. See Everett, Bentham in the United States of America, in JEREMY BENTHAM AND THE Law, supra note 7, at 185, 193.

14. See Letter from Plumer to Bentham (Sept. 15, 1826), reprinted in 10 BeNTHAM Works, supra note 2, at 556-57: "[Livingston] has often spoke of you to me in terms of the highest veneration and respect, and informed me, more than once, that his attenpts at Codification grew out of what he learnt of your views in the works published by Dumont. He considers you as his master in the service: and you could hardly deserve a more zealous or moro enlightened disciple." See also Letter from Livingston to Bentham (Aug. 10, 1829), reprinted in 11 BENTHAM WoRKS, supra note 2 , at 23.

15. C.H. HuNr, supra note 12 , at 83.

16. W. B. HATCHER, supra note 11, at 245-62.

17. Bentham appears to have realized this. He helped Livingston by arranging for needed material to be sent him, and he engineered the publication of Livingston's coinpleted Code in England and a favorable review in an English journal. See 11 BeNTHAM Works, supra note 2, at $35,37,51$.

18. See Letter from Livingston to Bentham (July 1, 1830), reprinted in 11 Benthus Works, supra note 2 , at 51 : "I . . . take pleasure in acknowledging, that although strongly impressed with defects of our actual system of penal law, yet the perusal of your works first gave method to my ideas, and taught me to consider legislation as a science governed by 
The legitimacy of law depended upon its being readily knowable and known by those it purported to govern. An integrated and self-contained body of written law that embraced all the law needed to decide cases, without resort to other sources, was essential to a rational system. The common law was to be deeply distrusted because it violated all these principles and because it constituted a charter to the judges to govern, and to govern in the worst way -through ex post facto laws grounded on the judges' own preferences masquerading as the product of legal logic and precedent. ${ }^{19}$ These ideas are now familiar, since they represented, in a somewhat diluted form, the core of the case for codification throughout the codification controversy of the nineteenth century. Livingston stood at the beginning.

The Penal Code Livingston submitted in 1826 to the Louisiana legislature bore the imprint of his Benthamite utilitarianisin. ${ }^{20} \mathrm{He}$ was well aware of it. Writing to Bentham in 1829 he said, "In laying before you this work [the Penal Code], I offer you little that you have not a legitimate title to; for, hereafter no one can in Criminal Jurisprudence, propose any favourable change that you liave not recommended, or inake any wise improvement, that your superior sagacity lias not suggested." 21

Livingston's Penal Code consisted of four separate codes covering over 650 pages-a Code of Crimes and Punishments, a Code of Procedure, a Code of Evidence, and a Code of Reform and Prison Discipline. None of the penal codes we shall be considering approached it in scope. That this vast project was coinpleted in two years almost entirely by one man preoccupied with law practice and other codes and then, when the first completed draft was destroyed by fire, was redone froin scratch after another two years, speaks volumes of the extraordinary spirit and ability of the author. ${ }^{22}$

Livingston's commitment to making the Code readily knowable and understood gave the Code a distinctive style. The definition of crimes sometimes entailed a unique blending of command and explanation. ${ }^{23}$ For example, before defining the circumstances in which persons might kill in executing judicial orders, the Code explained that since the public interest in executing judicial orders was so great that officials were obliged to risk their lives, justice required that they be permitted to defend themselves in performing this duty. ${ }^{24}$ The prohibition of conspiracies to fix

certain principles applicable to all its different branches, instead of an occasional exercise of powers called forth only on particular occasions, without relation to, or connexion with, each other."

19. See Introductory Report to the System of Penal Law, reprinted in 1 LIvingston Works, supra note 11 , at $87-95,148,163$.

20. See 1 LIVINGSTON WORKs, supra note 11, at 86-87: "I have taken truth for the foundation of all my statements, utility for the sole object of my provisions, and reason alone as the means of supporting my conclusions. ..."

21. 11 BENTHAM WORKS, supra note 2 , at 23.

22. C.H. HUNT, supra note 12, at 257-58; 1 Livingston Works, supra note 11 , at 81 . 159.

23. For Bentham's arguments for giving reasons, see 1 BeNrHAM Works, supra note 2 , at

24. Codi of CRIMes and PUnishments art. 499, reprinted in 2 Livingston Works, supra note 11 , at 130 . 
prices or wages followed a statement of the right of an individual to set the price of his own goods or the wages for his own services. ${ }^{25}$ Even inore often, the prohibitions were followed by illustrations. For example, article 484 of his draft declared one who voluntarily permits another to cause his own death to be guilty of homicide and added as an example of such homicide the case of a person who sees a blind inan walking to a precipice and declines to inform him of the danger; article 519(5) explicated the Ineaning of prudent caution with several illustrations involving the use of firearms and quarry-blasting.

Livingston further attempted to make the Code more fully understood through an early general statement of the notives and basic principles of the legislature in enacting the code. Livingston was particularly proud of this accomplishment. "In no other code that I have seen," he wrote, "has the legislator entered into a full and frank explanation with the people; told them what he intended to do, and for what reason; marked out the limits of the right course, and bade them observe whether he exceeded them. In no other has he treated them, in short, like reasonable beings, and told them to reflect as well as obey."26

It is in these general provisions that the Benthamite creed appears quite unobscured. ${ }^{27}$ Thus, the code stated: "Vengeance is unknown to the law." The only object of punishment is prevention which the law achieves by special deterrence of the delinquent and general deterrence of the rest of the community. Acts mjurious to the state and to persons should be made criminal; but to avoid multiplication of penal laws without "evident necessity," such acts should not be inade criminal when private suit is sufficient to repress thenr; neither should such acts be made crimes which can not be enforced, whether because of public opimion or otherwise. Laws should be written in plain, unequivocal language so that all can understand, and concisely so that all can remember; moreover they should be taught im schools and publicly read on stated occasions. ${ }^{28}$

Other Benthamite reflections appeared throughout Livingston's Code. One renarkable feature of the Code was its elimination of capital punishinent. In his earlier writings Bentham was apparently prepared to accept capital punishment for aggravated inurder. ${ }^{29}$ Not so Livimgston who, in his

25. Id. art. 689, reprinted in 2 LIVINGSToN Works, supra note 11 , at 180-81.

26. 1 LIVINGSTON WoRKS, supra note 11, at 237. at 3,14 .

27. Preamble to Draft Code and Book 1, reprinted in 2 Livingston Works, supra noto 11,

28. This is why he thought it indelicate to include the crime of homosexuality. But another reason was as modern as that reason was quaint: that it is susceptible of use (because of the difficulties of proof) as an engine of extortion. 1 LIVINGSTON Works, supra note 11, at 27. He also thought it couldn't happen in Louisiana, but we inay charitably pass that. None of the Penal Codes eliminated homosexual offenses until the Model Penal Code. Livingston did include the crime of adultery for married women. 2 id. at 286-87; CODE of CRIMES AND PUNISHMENTS art. 344, reprinted in 2 LIVINGSTON WORKs, supra note 11, at 97 . Bentham would havo eliminated both. Bentham, Offences Against Taste, in THB THEORY of LEgisLATION 476 (Ogden ed. 1931). 
Introductory Report to the Code of Crimes and Punishment, developed a long and powerful case to which little has since been added..$^{30}$

Perhaps the most pervasive Benthamite theme to be found in the Code is the distrust of judges. ${ }^{31}$ Common-law crimes, reference to common-law terms, and all means through which judges might infuse their own moral views into the definition of crimes were eliminated.32 Where the language of the Code proved uncertain in application despite the Code's attempt at clarity through unequivocal language, definitions, and illustrations, judges could not punish simply because they viewed the conduct as withm the spirit of the provision. To Livingston, better that evil acts go unpunished than that judges assume legisiative powers. ${ }^{33}$ Only one concession was made to statutory uncertainty-when the judge believed that the statute included conduct the legislature did not intend to penalize, he should acquit and should then report the case to the iegislature. ${ }^{34}$ Judiciai discretion in sentencing was harder to deal with. Livingston responded with a very large number of statutory punishment discriminations (at least ten different maximum and ten different minimum gradations, with numerous fractional imcreinents for aggravating circumstances) and a detailed specification of aggravating and mitigating circumstances to guide the judges' sentencing discretion, ${ }^{35}$ an innovation which was largely ignored until its use by the Modei Penal Code.

The Code sought to guard against judicial abuse in other ways as well. The power of a judge to loild a person in contempt for acts committed in court was eliminated. Instead, specific crimes of interfering with judicial proceedings were defined, triable through the ordinary criminal processes rather than summarily by the offended judge applying his own standard of offensiveness. ${ }^{36}$ The Code did not just remove the power to enjoin libeious or seditious writing froin the judge; it made any judge who granted such an injunction punishable by fine and suspension of political rights for two years. 37 Criminal penalties were provided for a range of judicial improprieties: receiving bribes or "Inaliciouly" doing a iegally unauthorized act; receiving a gift (other than a legacy) from anyone but close relatives; ${ }^{38}$ advising another judge or participating in cases of possible conflict of

29. 1 BENTHAMS Works, supra note 2 , at 450 .

30. 1 LIVINGSTON Works, supra note 11, at 185-224.

31. See Franklin, Concerning the Historic Importance of Edward Livingston, 11 TUL. L. RBv. 163, 182 (1937): "Livingston's thought represents the most concerted attack on judicial supremacy in the history of American law ...."

32. CODB OF CRTMES AND PUNISHMENTS art. 7, reprinted in 2 LIVINGSTON Works, supra note 11 , at 15 .

33. "An ambiguous penal law, is no law; and judicial decisions cannot explain it without usurping authority which does not belong to them." 1 LIvINGSTON Works, supra note 11, at 170.

34. Codb of Crimes and Punishments arts. 7,8 , reprinted in 2 Livingston Works, supta note 11 , at 15 . 294-95.

35. CODE OF Procadure art. 431, reprinted in 2 Livingston Works, supra note 11, at

36. Code of Crimes and Punishments arts. 205-208, reprinted in 2 Livingston Works, supra note 11 , at $59-60$.

37. Id. art. 243, reprinted in 2 LIvngsToN WoRKs, supra note 11, at 70-71.

38. Id. arts. 138-143, reprinted in 2 LIVINGSTON WORKS, supra note 11, at 44-45. 
interest. ${ }^{39}$ After a case had been tried no one could be punished for arguing against "the legality or propriety" of the decision. ${ }^{40} \mathrm{~A}$ judge (also an executive officer) who through official action interfered with freedom of speech or of the press was punishable by imprisonment for sixty days to six months and four years loss of his political rights. ${ }^{41}$

There is another side to the ideology underlying Livingston's Code, one not at all incoinpatible with Bentham's thought, but inore identified with the Jeffersonian ideas of revolutionary America and those of the Jacksonian democracy that were on the rise. ${ }^{42}$ In the area of the criminal process, for example, the Code went beyond the Bill of Rights formulations of the times: the accused was entitled to counsel at every stage of the proceedings, and if he was unable to provide one, the court was to appoint a lawyer to represent him; ${ }^{43}$ no confession was admissible against the accused unless "it be given freely." " 44 The Code employed the criminal law to protect the civil hberties of persons: it inade it a misdeineanor to attempt to prevent a person froin exercising his freedom of speech ${ }^{45}$ or his freedom to engage in his own religious worship ${ }^{46}$ through violence or threats to lis person or his property. Striking another modern chord, Livingston's Report stated that "[p]ublicity is an object of such importance in free governments, that it not only ought to be permitted, but must be secured by a species of compulsion." 47 Hence the judge was required to pronounce the reasons for his final judgment in criminal cases, which had to be available for public scrutiny and criticism. ${ }^{18}$ Even true statements could constitute criminal defamation when not nade for justifiable cause, but true statements about the conduct of officials were never illegal; ${ }^{49}$ mistaken comments about official actions or the motives of officials could not be prosecuted, so long as they did not falsely allege criminality. ${ }^{50}$ A inodern recognition of the inportance of privacy was shown in Livingston's treatment of "epistolatory correspondence": it was punislrable to open a letter addressed to another and more severely punishable nualiciously to publish its contents. 51

These provisions exhibited the libertarian spirit of Livingston's Code. Others reflect a broad hunianitarianism and social liberalism. His proposed abolition of capital punishment itself expressed these impulses. For though

39. Id. art. 146, reprinted in 2 LIvingston Works, supra note 11, at 46 .

40. Id. art. 20, reprinted in 2 LIVINGSTON WORKs, supra note 11, at 17.

41. Id. art. 240 , reprinted in 2 LIVINGSTON WorKs, supra note 11 , at 69-70.

42. An insightful treatment of the main thernes in Livingston's Code appears in Hall, Edward Livingston and His Louisiana Penal Code, 22 A.B.A.J. 191 (1936).

43. CODB of CRIMEs and PUNIShMents art. 15, reprinted in 2 Livingston Works, supta note 11 , at 16 .

44. Id. art. 12, reprinted in 2 Livingston Works, supra note 11 , at 16.

45. Id. art. 239, reprinted in 2 LIVINGSTON WoRKs, supra note 11 , at 69.

46. Id. art. 356, reprinted in 2 Irvingston Works, supra note 11, at 99.

47. 1 Lrvingston Works, supra note 11 , at 15 .

48. COde of Crimes and PUNishments atts. 19, 20, reprinted in 2 Livingston Works, supra note 11, at 17.

49. Id. art. 386, reprinted in 2 Livingston Works, supra note 11, at 104-05.

50. Id.

51. Id. arts. 621, 622, reprinted in 2 LIVINGSTON Works, supra noto 11, at 166. 
he argued its ineffectiveness and general disutility, in the end Livingston confessed his "firm religious belief ... [in] the truth of the doctrine" of total abolition..$^{52}$ His humanitarianism is nost vividly revealed in the fourth part of his Code, the Code of Reform and Prison Discipline..$^{53}$ In his Introductory Report to the Code he wrote with eloquence and feeling of the crimespawning nature of prisons, and provided in the Code for segregated confinement of young people, those awaiting trial for misdemeanors and those awaiting trial for more serious offenses. ${ }^{54}$ He provided for separate places of imprisonment after conviction, as well, for juveniles and those who committed misdemeanors of no great moral wrong. ${ }^{55}$ The conditions of imprisonment of such offenders were set out in the Code, and made subject to the discretion of the judge, "not according to the caprice of a turnkey." 56 For serious offenders, separately housed in the penitentiary, the conditions of imprisonment were to be directed to reformatory discipline and punishment at the same time, with as little suffering to the offender as was necessary to accomplish both objectives. ${ }^{57}$ Here too, the discretion of a jailer was limited. Labor, education, moral instruction were to be provided systematically so that the reform potential of imprisonment itself would be enhanced.58 Deprivation of wholesome food and drink were not to be instruments of punishment, althougl variations in quality of food and conditions of housing and labor could be used as a means of reforming the offender. ${ }^{59}$

Livingston regarded punishment and reform of offenders as only part of the proper social response to crime, however. These responses would be inadequate unless accompamied by efforts to strike at the "great sources of those offenses which send the greatest number to our prisons," which he believed to be "pauperism, mendicity, idleness, and vagrancy." ${ }^{0}$ Therefore, in addition to prisons for those who committed crimes, his Code provided for a House of Refuge and a House of Industry. The House of Refuge would provide employinent for those unable to support themselves on their own, as well as for discharged convicts who needed employment on the way back into society. The House of Industry would house beggars and vagrants who refused labor in the House of Refuge. In the words of the Code, the object of the House of Refuge was "to afford the means of voluntary eniployment to those who are able and willing to labour, and gratuitous support to those who are not"; the object of the House of Industry was "to coerce those who,

52. 1 Livingston Works, supra note 11, at 223. See Mackey, Edward Livingston on the Punishment of Death, 48 TuL. I. Rkv. 25 (1973).

53. See Roberts, Edward Livingston and American Penology, 37 LA. L. Rev. 1037 (1977); Smith, Edward Livingston, and the Louisiana Codes, 2 ColUM. L. Rev. 24 (1902).

54. Introductory Report to the Code of Reform and Prison Discipline, reprinted in 1 IIVINGSTON Works, supra note 11 , at 507, 537-89.

55. "A man of worth and integrity may be guilty of breaking the provisions of mere positive law; but it would be confounding all sense of proportion in punishment to conduct him to the same prison with the thief or assassin." Id. at 544-45.

56. Id. at 546 .

57. Id. at $547-48$.

58. Id. at 555-56.

59 . Id. at 558 .

$60 . I d$. at 528 . 
although capable of supporting themselves, prefer a life of idleness, vice, and mendicity, to one of honest labour." 61

Responding to the arguments against his scheme, Livingston articulated themes suggesting a social-democratic philosophy. The duty of private charity was not to be preferred over "that social duty which every nation owes to the individuals which compose it; which duty is not only protection, but mutual support." 62 Society owed protection to individuals from famine as well as the sword. The protection of property was secondary to the protection of life. Thus, the imposition of burdens on the property of some so that others might survive was an obligation of society. "[C]an it be supposed that any just contract," Livingston wrote, referring to the notion of the social contract, "could stipulate that one of the contracting parties should die of hunger, in order that the others might enjoy, without deduction, the whole of their property? The obligation, then, if derived from the only source to which we can look for its conditions, includes support as well as protection." 63

The state of the criminal law in Louisiana at the time of Livingston's Code-remnants of French and Spanish law, overlaid with a variety of statutory enactments and the common law itself-would seem to have made it ripe for a codification victory. Yet the effort failed, both in Louisiana and as a direct model elsewhere. ${ }^{64}$ The reasons are many and complex.65 But Livingston's veheinent attack on the judges and his proposals to limit their authority, as well as his other radical ideas, such as his attempt to make the problem of uneinployment part of the probleun of crime, probably alienated the commercial, slave-holding society of Louisiana in that day. ${ }^{68}$ Livingston's triumph lay not in enacted codes, but in the judgment of his peers, one of whom, Sir Henry Maine, thought him to be "the first legal genius of modern times." 67

\section{Thomas Babington Macaulay}

Thoinas Babington Macaulay, the draftsman of the proposed Indian Penal Code of 1837, followed next in the line of codifiers. Like Livingston, Macaulay was a man of affairs. He held a variety of administrative positions in government and served as a member of Parliament on and off for nuch of his career. Unlike Livingston (and unlike all the codifiers discussed

61. Codi of Reform and Prison Disctpline art. 294, reprinted in 2 Livinoston Works, supra note 11, at 598 .

62. 1 LIVINGSTON WorKs, supra note 11 , at 533.

63. Id. at 533-34.

64. Apparently Guatemala adopted the Code of Reform and Prison Discipline in Spanish translation. See C.H. HuNr, supra note 12, at 279.

65. See Beckman, Three Penal Codes Compared, 10 AM. J. LBgal Hist. 148, 166-67 (1966).

66. See Franklin, Concerning the Historic Importance of Edward Livingston, 11 TUL. L. REv. 163, 209-12 (1937).

67. C.H. HUNT, supra note 12, at 278. For other testimonials and recognition, see Moore, supra note 9 , at $344,355-60$. 
here), he was barely a lawyer. As a young man he was called to the bar, but his practice, as he said, was "extremely small." ${ }^{88}$ Moreover, his principal career was devoted to historical scholarship; it is as the author of the History of England and other historical and hiterary books and essays that he established his renown. It is sobering indeed for legal educators to realize that one of the great codes of law was written by an historian and man of letters with a mere sinattering of legal training.

As a member of Parkiament, Macaulay played an important part in the debates leading to the enactment of the India Charter Act of $1833^{69} \mathrm{He}$ and others succeeded in incorporating a provision that laid the basis for Indian law codification. This provision declared that a general judicial systein and common body of laws applicable to Europeans and natives slould be enacted, with due regard to the "rights, feelings and peculiar usages of the People," and that to that end existing laws and customs should be ascertained, consolidated, and amended where required. It directed the Governor General in Council (constituting the British Government in India and sometimes also referred to as the Supreine Council of India) to appoint a body of experts, known as the Indian Law Commission, to make reports and recommendations to carry out these objectives. ${ }^{70}$

Macaulay was soon appointed to the Supreme Council and later became Cliairman of a four-man Indian Law Commission, appointed by the Supreme Council as directed by the Charter Act. ${ }^{71}$ The task of the Commission was to prepare "a code of laws common (as far as may be) to the whole people of India, and having its varieties classified and systeinatized. . . "72 Thus was Macaulay provided with a key role in a plan for the coinprehensive codification of laws for India. He einbraced the task with enthusiasm, impelled by a plan for codification and reform that probably exceeded the terms of his commission. ${ }^{73}$

Unfortunately, for a variety of reasons best told in Professor Stokes's study, ${ }^{74}$ the plan was never accomplished. The Indian Penal Code-though without the accompanying Codes of Procedure and Prison Discipline that Macaulay thought essential ${ }^{75}$ - was the only significant success of the codi-

68. "My own forensic experience, gentlemen, has been extremely small; for my only recollection of an achievement that way is that at quarter sessions I once convicted a boy of stealing a parcel of cocks and hens." 1 G.O. TREVELYAN, LIFE AND LeTTERS OF LORD MACAULAY 368 n.1. (1876).

69. E. Stokes, The ENGlish Utilitarians aNd INDIA 191 (1959).

70. India Charter Act, 1833,3 \& 4 Will. IV, c. $85, \$ 53$. A discussion of the historical context and contents of the Charter Act of 1833 may be found in C. Ilbert, Thr GoverNMENT OF INDIA 81-89 (3d ed. 1915).

71. See 1 G.O. TREVELYAN, supra note 68 , at 343 (1876).

72. Public Dispatch of 10 December 1834, reproduced in C. Ilbert, The Government of INDIA 492 (1898), quoted in E. STOKES, supra note 69, at 193.

73. See J. Clive, Macaulay: The Shaping of the Historian 435 (1973). In a letter to his barrister-friend, Ellis, at this time he wrote: "I have immense reforms in hand such as you Knight Templars would abhor, but such as would make old Bentham jump in his grave-oral pleadings-examination of parties-single seated justice-no institution fees-and so forth." E. STOKES, supra note 69 , at 213 n.4.

74. E. STokes, supra note 69 , at $190-233$.

75. Macaulay vrote to Hobliouse in 1835: "our criminal code, whatever credit it may do us in the opinion of Benthamites at home, will do very little good to the people of this 
fication movement in India during this period (and even that lay unenacted for over 20 years after its completion). Because of illness and other reasons, the three other members of the Indian Law Commission participated very little in the work of preparing the Code. Virtually the entire burden of drafting the Code, therefore, fell on Macaulay; ${ }^{76}$ he accomplished the job within two short years, 1835 to 1837 , while attending to other governmental and legislative duties, continuing his essay writing, and keeping up with his Greek in the evenings. ${ }^{77}$

Three features of Macaulay's thought and personality affected the style and substance of his Code. Like Livingston, Macaulay was a utilitarian in the Benthamite tradition, an influence imparted early as a member of the "Clapham sect" at Cambridge. ${ }^{78} \mathrm{He}$ shared fully the premises of the tradition with respect to the unacceptability of judge-made law; the desirability of a root-and-branch legislative remaking of the law responding to what it ought to be, judged by the utility ethic; ${ }^{79}$ the distaste for sinall, piecemeal reforms; and the high regard for clarity, brevity, and simplicity in legal statement as the means of enhancing the knowledge of the law by those it affects. ${ }^{80}$

At the same time, Macaulay was an unremitting Whig in politics; he departed from those implications of the Benthamite creed (quite fully embraced by Livingston) that favored a large role for the state in redressing social evils and dislocations. Comprehensive codification in the style of Bentham he favored fully, but only to render the administration of law more efficient and rational, not to restructure society. ${ }^{81}$ Moreover, while he was a libertarian, Macaulay did not share Livingston's passionate democratic impulses and was unsympathetic to undermining the status of governmental authority.

In addition, Macaulay was not a man of speculative, philosophical bent. ${ }^{82}$ As an historian he was an elegant and gripping story-teller, whose power arose from the virtuosity of his prose, his command of facts, and his erudition; as a politician he was hardheaded, pragmatic, and expedient-a

country, until it be accompanied by a thorough reform of prison-discipline." J. CLrvB, supra note 73 , at 448 .

76. Id. at 440 .

77. 1 G.O. TREVELYAN, supra note 68 , at 419.

78. Stephen, Macaulay, in 12 Dicrionary of National Brography 411 (1921).

79. See J. ClIVE, supra note 73, at 453: "The philosophical, Benthamite, approach to codification was to think of law as it ought to be as well as law as it was; to dissect every idea; to ask of every rule what useful purpose it served."

80. "I am firmly convinced that the style of laws is of scarcely less importance than their substance. When we are laying down the rules according to which millions are, at their peril, to shape their actions, we are surely bound to put those rules into such a form that it shall not sequire any painful effort of attention or any extraordinary quickness of intellect to comprohend them." Macaulay, Minute (May 11, 1835) quoted in E. STokes, supra note 69, at 199.

81. See E. Stokes, supra note 69, at 191-92.

82. See Stephen, supra note 78, at 417 :

The tenets of the Whig party were for him the last word of political wisdom. The essay on Bacon is a dehberate declaration of the worthlessness of all speculation not adapted to immediate utility. His attack upon the utilitarians expresses a moro thorough-going empiricism than that of their ofn official advocates. ... The philosophical and imaginative tendencies represented by such men as Wordsworth, Coleridge, or Carlyle, struck him as mere mystical moonshine. 
man of "sturdy common sense" with "a very hard kernel of business in him." ${ }^{83}$ As a draftsman-codifier he combined both sets of qualities.

Turning now to how these three aspects of Macaulay-his Benthamism, his Whig preferences, his practical-mindedness-are reflected in his Penal Code, I start with his Benthamism. The cliaotic condition of the criminal law in India at the time presented an extraordinary opportunity for a Benthamite codification, as Bentham had earlier perceived.84 The variety of overlapping laws of different provenance and indeterminate authority that characterized Livingston's Louisiana also characterized India. Muslim and Hindu law, the East India Coinpany's regulations, and the common law itself, all competed in uncertain application. The criminality of a person's actions often depended on who he was-his caste, his religion, whether English or native-and on which of the presidencies he happened to be tried in. Much of the Muslim law was cruel, bizarre, and arbitrary to Englislı eyes. ${ }^{85}$ All this afforded Macaulay the justification for largely ignoring the existing Indian law in framing a fresh Penal Code. ${ }^{86}$

Macaulay stated that no other system of penal law provided even a "ground work" for his code. ${ }^{87}$ This is an arguable issue. He acknowledged assistance from the French Code and the French decisions, and "still inore valuable" assistance froin Livingston's Code, but it is clear enough that these were not his groundwork..$^{88} \mathrm{~A}$ number of commentators, lowever, seeing the many parallels with English law in concept and structure, if not in language, have concluded that the Code in substance enbodied (if unconsciously) the English common law. ${ }^{89}$ Fitzjames Stephen, for example, described the Code "as the criminal law in England freed froin all technicalities and superfluities, systematically arranged and modified in some few particulars ... to suit the circumstances of British India." 80 No doubt there is much of the English criminal law in the Code, but Professor Fitzgerald has probably come closest

83. Clive, Macaulay, in 9 International Encyclopedia of the Sochal Sciences 499 (1968).

84. J. Bentham, On the Influence of Time and Place in Matters of Legislation, in 1 BENTHAMI Works, supra note 2 , at 169.

85. See A Penal Code Prepared by the Indian law Commissioners i-iv (1838) [hereinafter cited as INDIA PENaL CODE]. The criminal laws prevailing in India at the time are described in great detail in J. ClIVE, supra note 73, at 437; M. LaNG, Codification IN THB British Empire AND AMeriCA $69-76$ (1924); Banerjee, The Substantive Criminal Law Prior to the Indian Penal Code, in 1 Indian Law Institute, Essays on thr INDian PENaL Code 1 (1961).

86. India Penal CoDe, supra note 85, at i: "the system of penal law which we propose is not a digest of any existing system, and . . . no existing system has furnished us even with a ground work."

87. Id. at $\mathrm{i}$, iv.

88. He follows his acknowledgment of Livingston's assistance with the comment: "We are the more desirous to acknowledge our obligation to that eminent jurist because we have found ourselves under the necessity of counbatting his opinions on some iniportant questions." Id. at iv. See, e.g., id at 72, 73, 75 note (fines), 104 note (omissions), note 106-09 (homicide) (discussion of Livingston's Code). But he rejected Livingston's provisions in almost every instance.

89. See $3 \mathrm{~J}$. Stephen, History of the Crimmat LaW of England 300 (1883); $1 \mathrm{~W}$. Stokes, The Anglo-Indian Codes xxvi (1887); M. Setalvad, The Common Law in India 126-29 (1960); Rankin, The Indian Penal Code, 60 LAw Q. Rev. 37, $42-43$ (1944).

90. 3 J. STEPHEN, supra note 89 , at 300 . 
to the nub in observing, in reference to Stephen's statement: "Is it irreverent to suggest that English Criminal Law, 'Freed from all technicalities and ambiguities and systematically arranged', has undergone such a metamorphosis as to be an entirely new thing?" 01

Macaulay's general outlook on British rule in India obviously bears on any inquiry into his position on the uses of English law in Indian codification. For Macaulay, what England could best do for India was to serve as the instrument of its modernization, which Macaulay took as tantamount to its Anghicization, or at least its Europeanization. This can fairly be viewed as an instance of arrogant British provincialism ${ }^{22}$-the notion that native cultural values and forms were inferior to Western ones-and as a strategy of imperialism, involving the destruction of an indigenous national and individual identity. ${ }^{03}$ That sentiment is plain in Macaulay's famous 1835 Minute on Indian education, which was influential in establishing the English language as the principal ineans of instruction in the new national system of education. ${ }^{94}$ But though Macaulay was a colonialist, it inust be remembered that the existing alternative to his approach was not one built on the anticolonial values of self-determination and autononry. These values had yet to emerge in British politics. The approach that Macaulay opposed was the typical approach of British colonial administrators for much of the 19th century-one founded on a paternalism that sought to maintam Indian backwardness in the interests of British rule and that was justified by a glorification of inherited tradition and a distrust of all social change.95 Macaulay sought to further British interests differently-through a farreaching Europeanization that would lead to a nodern India, one that would nake the benefits of a modern state available to the Indians.

Macaulay's assimilationist colonial policy, therefore, does suggest a strong reason for him to have looked to English law for his "ground work." One might, nonetheless, find some evidence that he did not in the many concessions his Code made to local customs, conditions, and sensibilities. For example, transportation was retamed because native fear of it made it a powerful sanction; ${ }^{96}$ the privilege of self-defense was drawn liberally because he believed Indians to be too meek in the face of aggression; ${ }^{97}$ and, offenses

91. Vesey-FitzGerald, Bentham and the Indian Codes, in JEREMx BENTHAM AND THB LAw, supra note 7, at 222, 227. He further observes, "That the Indian Penal Code is founded on English Criminal Law is true only in the sense in which it might be contended that without a Blackstone to excite his critical faculty we might never have had a Bentham:" Id.

92. See Brinton, Macaulay, in 10 ENCYCLOPEDIA OF the SOctai Sciences 648 (1935).

93. See E. ERICKSON, GaNDHI's TRUTH 276 (1969), which includes this telling sentence from Macaulay's Minute on Indian education: "We must at present do our best to form a class who may be interpreters between us and the millions whom we govern; a class of persons, Indian in blood and colour, but English in taste, in opinions, in morals, and in intellect."

94. "A single shelf of a good European library was worth the whole native literature of India and Arabia. ... Neither as the languages of the law, nor as the languages of religion, have the Sanskrit and Arabic any peculiar claim to our engagement." T. MACAULAY, ProsB AND POETRY 729 (1852), quoted in E. ERIKSON, supra note 93, at 276.

95. See 1 W. STOKES, supra note 89 , at xvi.

96. INDIA PENAL CODE, supra note 85 , at 70 note.

97. Id. at 81-82 note. 
dealing with religion were drawn in deference to the peculiar religious sensibilities of Indians. ${ }^{88}$ But these concessions do not refute the argument that Macaulay's Code assimilated English law. The Charter Act itself required "due Regard . . . to the Rights, Feelings, and peculiar Usages of the People" in drafting legislation. ${ }^{99}$ More significantly, the instances of deference were inarginal and did not greatly affect the overall structure of the Code; they represented the kind of accommodation to local conditions that sound colonial government of the times saw as transitionally necessary. To be sure, Macaulay did say in his covering letter to the Governor General that he would have been inclined simply to digest Indian law and only noderately correct it if the law had found favor with the people. ${ }^{100}$ But this was written as an excuse for not adhering to the Charter Act's direction to liave regard to the existing law and may, especially viewed in light of Macaulay's philosophy, be fairly regarded as a diplomatic pre-emptive defense.

The strongest argument against the view that Macaulay's Code resembled his Minute on education in imposing Englisl nuores on India is that, in marked contrast to Englislı culture and language generally, he held the English law as it stood in contenupt. Modernization of the Indian criminal law he certainly sought, but not a modernization which imvolved the transplanting of English law. Instead, le sought for England as well as for India a wholesale redoing of the criminal law, rooted in a "universal science of jurisprudence." As Professor Stokes observed, "to neglect this universality of outlook, this cast of mind that was of the 18th century philosophe, is to lose the historical atunosphere in which the Code took shape." 101

The style of presentation of a code was of great concern to Bentham. But he sought to achieve through that style objectives that, in practice, are difficult to achieve together. The code should speak in the language of command and yet integrate statements of reasons to serve both as a mieans for popular accountability of the legislature and for greater understanding by the citizen of why he should comply. ${ }^{102}$ The language sliould be clear, brief, and simple for ready understanding even by the less sophisticated, yet it should draw lines between the permitted and the prohibited with such elegant precision as to leave no room for judicial lawmaking. ${ }^{103}$ Macaulay, though least the lawyer, was much the most acconplished stylist of the Benthamite codifiers, and came closest to achieving those prescriptions. Of

98. Id. at 102 note. For other examples, see discussion in $\mathrm{J}$. CLIVE, supra note 73 , at 452-55; 1 W. STOKES, supra note 89, at xxvi; Rankin, supra note 89, at 45-46.

99. India Charter Act, 1833, 3 \& 4 Will. iv, c.85.

100. INDIA PENAL CODE, supra note 85 , at $i$.

101. E. Stokzs, supra note 69, at 227. See Vesey-FitzGerald, supra note 91, at 231:

But it was Bentham's peculiar merit that he taught lawyers-at any rate lawyers of the high quality of those who framed the Indian Codes-to think always of the law as a symmetrical and logical whole and of the law not merely as it is but as it ought to be; to dissect every idea; to base theinselves always on first principles and to ask of every rule, "what useful purpose does this serve?"

102. J. BenThaM, Codification Proposal, in 4 Bentham Works, supra note 2, at 543-45. 103. India Penai CODE, supra note 85, at v. 
precious few legal works, let alone a code of law, is it imaginable that a perceptive scholar could credibly say what Clive said of Macaulay's Code: "[I]t . . . turns out to be at one level what Bagehot called The Wealth of Nations-an amusing book, imbued with the knowledge, learning, and stylistic vigor of its author." 104

Unlike Livingston, Macaulay did not interweave the legislative reasons with the proscriptive features of the code, as Bentham proposed. ${ }^{105} \mathrm{He}$ did append a set of Notes containing the reasons for those provisions that seemed to require explanation or defense. ${ }^{108}$ But the Notes were addressed to the legislature as reasons to adopt rather than to the public as reasons to comply, as Bentham contemplated; they were not part of the Code Macaulay proposed for adoption and were not so adopted in 1860 when the Penal Code was finally enacted.

The clarity and vigor of the Code's style was largely a product of Macaulay's peculiar talents. He followed a technique, however, that no doubt strengthened the effect. Stephen identified its elements as follows: "In the first place the leading idea to be laid down is stated in the most explicit and pointed form which can be devised." 107 Thus, in dealing with "mischief," article 399 first stated that whoever causes the destruction of any property or any cliange in it that diminislies its value, intending wrongful loss to any party, commits mischief. "Then such expressions in it as are not regarded as being sufficiently explicit are made the subject of definite explanations." The "Explanation" stated a person can not commit mischief to his own property. "This is followed by equally definite exceptions . . . ." The "Exception" in this article was that mischief did not imclude anything a person did openly with the good faith intention of saving anyone from death or hurt or of preventing a greater loss of property than that which he occasioned. "[A]nd in order to set the whole in the clearest possible light the matter thus explained and qualified is illustrated by a number of concrete cases." The article on mischief concluded with nine illustrations (witl " $\mathrm{A}$ " imvariably the actor and "Z" the victim) consisting of short hypotheticals to exhibit the law in apphcation. For example, illustration (g) stated: "A, laving joint property with $\mathrm{Z}$ in a liorse, slioots the horse, intending thereby to cause wrongful loss to $\mathrm{Z}$. A has committed mischief."

Macaulay put great stock in these illustrations as a way of inaking unmistakable to the unprofessional reader what the use of unfamiliar terms and locutions, unavoidable in the interests of precision, would otherwise make perplexing. In this way "the Code will be at once a statute book and a collection of decided cases: . . . cases decided not by judges but by the

104. J. CLIVE, supra note 73 , at 459.

105. J. Bentham, Essay on the Promulgation of Laws and the Reasons Thereof, With Specimen of a Penal Code, in 1 Bentham Works, supra note 2, at 159-63. J. BenthuM, supra note 102, at 543 ("Rationale, intervoven not detached."). One reason Macaulay choso to omit the reasons, apparently, was his expectation of difficulty in obtaining legislative consensus. See E. STOKES, supra note 69, at 199-200.

106. INDIA PENAL CODE, supra note 85, at iv.

107. 3 J. STEPHEN, supra note 89, at 302-03. 
legislature. . . "108 Macaulay was not "the first to use them in practical legislation," ${ }^{109}$ as has often been said. ${ }^{110}$ Livingston before him used illustrations in the body of his Code and for much the same reasons later advanced by Macaulay, ${ }^{111}$ though Macaulay used them far more elaborately and extensively. These illustrations met with great success in India. They were carried into the version of Macaulay's Code later adopted; they are still to be found, though much attenuated, in modern versions of the Penal Code ${ }^{112}$ and in the other Anglo-Indian Codes as well; ${ }^{113}$ they are even today frequently used by the Indian courts, ${ }^{114}$ and their use has been applauded "as an instrument of new constructive power, enabling the legislature, to combine the good points of statute-law and case-law . . . while avoiding almost all their respective drawbacks." 115 Nonetheless, the use of examples has not found favor in subsequent codification efforts. The American Restatements contaim the only instance of their use of which I am aware, but these are not codes, model or otherwise, or even laws. Perhaps the most common reason for not using examples was given by the English Commissioners on Criminal Law in their Fourth Report.118 They reasoned that if the illustration falls clearly within the rule there is no need for it as part of the law; and if it is needed to remove some doubt then the terms of the rule are thereby shown to be imperfect and should themselves be redrawn. 117

One of the leading goals of Benthamite codifications like Macaulay's was to set forth the whole of the penal law with such simplicity and clarity that the average citizen would be able to understand it and the average judge would be unable not to. Stephen's comments, therefore, written in 1883, some twenty years after the enactment of Macaulay's Code, are a remarkable tribute to its success: "Till I had been in India I could not have believed it to be possible that so extensive a body of law could be made so generally known to all whom it concerned in its minutest details. . . . After twenty years' use it is still true that any one who wants to know what the criminal law of India is has only to read the Penal Code with a common use of memory and attention." 118

So much, then, for Macaulay's Benthamism. His Whig proclivities were most evident, and the contrast with Livingston greatest, on the large issues of the relation between the individual and the state. There was, for example, no

108. INDIA PeNaL CoDE, supra note 85 , at v.

109. 1 W. STOKES, supra note 89 , at xxiv.

110. See, e.g., M. LANG, supra note 85, at 81; F. Pollack, A Digest of THB LaW of PARTNERSAIP iv (4th ed. 1888); E. StoKes, supta note 69, at 231.

111. 1 LIVINGSTON WoRKS, supra note 11, at 178-79.

112. See R. Rantanlal \& K. Dhirajlal, The LaW of Crimes (22d ed. 1971).

113. 1 W. STOKES, supra note 89 , at xxvi.

114. M.C. SeTalVAD, supra note 89, at 129-30.

115. F. Pollock, supra note 110, at iv. See also 3 J. STEPHEN, supra note 89, at 302-03.

116. Her Majesty's Commissioners on Crimtnal LaW, Fourth Report, CD. No. 168, at xvi (1839), reprinted in 3 British Parltamentary Papers (Criminat LaW) 233, 248 (I.U.P. 1971) [hereinafter cited as PARL. PAP.].

117. Stephen appreciated the value of illustrations but believed they would be unacceptable to the English Parliament and to the English judges. 3 J. STEPHEN, supra note 89, at 304.

118. Id. at 322 . 
suggestion of anything comparable to Livingston's plan to have the state undertake a large program of unemployment relief as part of the attack on crime. Simce he sliared fully the traditional Whig bibertarianism and dislike of large government, ${ }^{119}$ Macaulay did not accept those elements of Bentliamism that cast on the state the duty to establish large bureaucratic enterprises to ameliorate social and economic conditions. ${ }^{120}$ This is not to say that Macaulay believed that the penal law might not be used to nudge some social change. He proposed that there be no immunity of a master for crimes he committed against his slaves because the absence of such an immunity would help to end slavery. ${ }^{121} \mathrm{He}$ also proposed excluding the crime of adultery for women in part to counter the unjust subjugation of women in India. ${ }^{122}$ These instances were far removed, however, from governmental undertakings to reinake the social structure.

Macaulay was surely no anti-civil libertarian. Contrary to the laws prevailing at the time, and to Livingston's Code as well, lie proposed that the truth of a prejudicial imputation be a full defense to criminal defamation in all cases. ${ }^{123} \mathrm{He}$ also imcluded provisions penalizing actions that insulted religious sensibilities or that interfered with the exercise of rehgious worship, ${ }^{124}$ not ouly because they reflected a principle expedient for conditions in India, but because the principle was one "on which it would be desirable that all Governments should act."12s Nonetheless, his Code did not reflect the same passion for democratic freedoms one finds in Livingston. For example, there were no provisions criminalizing actions that interfered with freedom of speech and the press. Where Livingston restricted the crime of sedition to enlisting men or making other preparations to subvert the state, or to utterances designed to counsel to such actions, ${ }^{120}$ Macaulay made punishable the use of words to "excite feelings of disaffection to the Government."127

Particularly revealing on the issues of state authority and individual freedoin were the provisions concerning a citizen's duty to coinply with official orders that might be illegal. The Code gave no right of private

119. E. STokes, supra note 69 , at 192.

120. See, e.g., 9 BENTHAM WORRS, supra note 2, at 213-64 (bureaucracy contemplated in his Constitutional Code). See also J. CuIve, supra note 73, at 433-34.

121. India Penal CoDe, supra note 85, at 85 note.

122. Id. at 131 note. "It would weaken a class already too weak. It will be time enough to guard the matrimonial contract by penal sanctions when that contract becomes just, reasonable, and mutually beneficial."

123. Id. cl. 470, at 64. Paradoxically, John Stuart Mill criticized this provision on the ground that the truth of charges relating to private life would be too difficult to adjudicate. Review of A Penal Code prepared by the Indian Law Commissioners, 31 LoNDoN \& WesTMINSTER REV. 393, 403-04 (1839) (unsigned, but generally attributed to Mill); see, e.g., J. Clrve, supra note 73, at 462; E. STOKEs, supra note 69, at 239.

124. India Penal CODE, supra note 85 , cls. 275-86, at 36-37.

125. Id. at 101 note.

126. Code of Crimes and Punishments arts. 110-14, reprinted in 2 Livingston Works, supra note 11, at 38-39.

127. India PENal CODE, supra note 85 , cl. 113, at 16. Although he did include an "explanation" stating that disapprobation of governmental measures "compatible with a disposition to render obedience to the lavful authority of the Government" is not "disaffection." 
defense against an action by an official that the official was legally competent to undertake, even if that action was illegal and itself constituted an offense. ${ }^{128}$ Thus, resistance to an illegal arrest was not permitted. No action was an offense that was done by a person who beheved "in good faith" that he was either compelled by law or authorized by law to do it. ${ }^{120}$ Since "good faith" as used by Macaulay in various portions of the Code ${ }^{130}$ as well as in these articles ${ }^{131}$ appeared to posit only a subjective standard (i.e., the absence of bad faith) ${ }^{132}$ the weighting was heavy on the side of authority in the balance between the state and the individual. Consistent with Whig political values, the state had a limited role but within that role its authority was great.

Macaulay's treatment of omissions was also consistent with his Whig outlook. He was not prepared to join Livingston in imposing a criminal duty on all persons to act to save others; that duty should extend only to those who otherwise have a legal duty to act.133 Only in part did this view result from the practical difficulty of legislating an acceptable line that would protect the imdividual when the burdens of actions were too great. More important was Macaulay's position, frequently reiterated, that private virtue should be left to other instrumentalities and that the coercive sanctions of punishment should be restricted to preventing men from doing positive harm to others. ${ }^{134}$

Though distinguished commentators have found in the Code evidence of Macaulay's humanitarianisin, ${ }^{135} \mathrm{I}$ do not myself find it heavily displayed. He did restrict capital punishment to murder and treason, but his reasons were practical, not humanitarian. ${ }^{136}$ Similarly, he favored the elimination of corporal punishment because it fell unevenly and most heavily on those

128. Id. cl. 75, at 10.

129. Id. cls. 62,63 , at 7 .

130. E.g., id. cls. 471-78, at 64-66 (defamation), where "good faith" belief in such non-factual matters as opinion and aesthetic judgment are made defenses to defamation.

131. Id. cl. 63, at 7, speaks of an action "done by a person in the exercise, to the best of his judgment exercised in good faith of any power given to bim by law," whicli would be odd if "good faith" imported an objective standard of reasonableness.

132. Later changes to Macaulay's Code as enacted included a provision expressly stating otherwise. $1 \mathrm{~W}$. Stokes, supra note 89, at 103: "Nothing is said to be done or believed in good faith, which is done or believed without due care and attention."

133. INDIA PENAL CODE, supra note 85, cl. 294, at 38.

134. Id. at 105 note. "In general however the penal law must content itself with keeping men from doing positive harm, and must leave to public opinion, and to the teachers of morality and religion, the office of furnishing men with motives for doing positive good." The same libertarian position appears in his reasons for not making adultery a crime:

We cannot admit tliat a Penal Code is by any means to be considered as a body of ethics, that the legislature ought to punish acts merely because those acts are immoral, or that because an act is not punished at all it follows that the legislature considers that act as innocent. Many things which are not punishable are morally worse than many things which are punishable.

$I d$. at 130 note. Compare the quite different perspective of Livingston in defending his proposal to criminalize indecent advances to women. 1 LIVINGSTON WORKS, supra note 11, at 286.

135. See, e.g., J. Cirve, supra note 73, at 447-48; Rankin, supra note 89, at 47.

136. INDIA PENAL CODE, supra note 85, at 69-70 note. 
with higher sensitivities, and not because it was inhumane. ${ }^{137}$ Much the same may be said of Macaulay's proposals for the treatment of offenders. Though no Code of Prison Discipline was completed, a report of the Law Commission on this subject, in which Macaulay participated, was submitted. ${ }^{138}$ Nothing can be found of Livingston's sympathy for the social unfortunates that are led to a life of crime, nor any programs for their rehabilitation, but only a stern special deterrence program built on "solitary confinement," "monotonous, uninteresting labour within doors," and deprivation "of every indulgence not absolutely necessary to health." 180 Indeed, Macaulay explicitly advanced the view that prison conditions should be as severe and intense as public sensibilities would tolerate-on the premise that the same amount of deterrence could thereby be obtaimed with sliorter prison terms. ${ }^{140}$

Finally, there is Macaulay's non-ideological and pragmatic side. It is evident in several of the Code's provisions already mentioned, but certain other features of the Code reveal these qualities with particular sharpness. Livingston, a very different sort of man, thought that his ringing statement of fundamental principles with which he opened his Code were among his most constructive innovations. ${ }^{141}$ Macaulay had no use for them. As a tough-minded, practical man, he liad little taste for grand pronouncements of penological philosophy and no nnore confidence in their utility for solving concrete problems. If statements of general principle were drawn tightly enough to have meaning they could prove embarrassingly tight for practical adjustments and compromises. If, on the other hand, they were loose enough to allow adjustments they were likely to be aphoristic and empty. A man of Macaulay's turn of mind avoids them. ${ }^{142}$

Macaulay quite thoroughly disapproved of judicial lawmaking, as did all codifiers in the Benthamite tradition. ${ }^{143} \mathrm{He}$ was prepared, however, far more than Livingston, to tolerate a judicial role when the alternative appeared impractical or productive of worse evils. Where Livingston tried to construct legislative solutions to some typical problems of causation in homicide (e.g., neglect or maltreatment of slight wounds resulting in death), ${ }^{144}$ Macaulay, after slowing that these formulations could be both

137. Id. at 77 note:

If it were possible to devise a punishment, which should give pain proportioned to the degree in which the offender was shameless, hard-hearted, and abandoned to vice, such a punishment would be the nrost effective neans of protecting society. On the other hand of all punishments the nost absurd is that which produces pain proportioned to the degree in which the offender retains the sentiments of an honest man.

138. E. STOKES, supra note 69 , at 217-18. 217-18.

139. SUMMARY Op REPORT OP LAW COMMISSION, quoted in E. STOKBS, supra note 69, at

140. India Penal, Code, supra note 85 , at 70 note.

141. See id. at $\mathrm{xx}$.

142. Cf. 1 W. STokes, supra note 89 , at 26 "'The framers of the Code do not seem to have troubled themselves much about the rival theories of punishment, respecting which German jurists and philosophers have written so copiously.").

143. INDIA PENAI, CoDE, supra note 85 , at vi.

144. CODE OF CRIMES AND PUNISHMENTS arts. 487, 488, reprinted in 2 LIVINGSTON WORKS, supra note 11 , at 127,128 . 
over- and under-inclusive, concluded that causation issues should best "be left a question of evidence to be decided by the Courts, according to the circumstances of every case."145 Where Livingston sought to control judicial discretion in imposing prison terms by providing an extremely large number of punishment gradations for different offences, ${ }^{148}$ Macaulay's Code included considerably fewer maximum gradations and used a minimum only for a few crimes. ${ }^{147}$ Livingston sought to prevent judicial excesses in fining the poor by prohibiting a fine greater than one-fourth of the offender's property. ${ }^{148}$ Macaulay reasoned that this prohibition would be impractical, in requiring lengthy and unsatisfactory investigations into the offender's wealth, as well as unwise, in preventing the court, where appropiriate, from requiring the offender to disgorge the whole of the profit inade from his wrong. He concluded that judicial discretion over fines was an evil that had to be endured if fines were to be used. ${ }^{149}$ Where Livingston sought, in the provisions on theft offenses, to deal definitively with the problem of defining "possession,"160 Macaulay, after deftly poking a few holes in Livingston's formulation, concluded that it was better to "leave it to the tribunals, without any direction, to determine whether particular property is at a particular time in the possession of a particular person, or not."151 Livingston's adherence to the primacy of life led him to the doctrine that verbal insults could not constitute sufficient provocation. ${ }^{152}$ Macaulay, aware of the impracticality of such a rule, especially in light of the high Indian sensitivity to mjuries to feelings, provided otherwise. ${ }^{153}$

Two other provisions that show Macaulay's sense of the practical are noteworthy because they represent innovations that have been adopted in subsequent legislation. One is his provision for dealing with what lie regarded as the ineradicable indistinctness of the lines separating theft, criminal misappropriation of property not $\mathrm{m}$ possession, and criminal breaches of trust. ${ }^{154}$ Since these distinctions were irrelevant to whether a person was punishable, Macaulay provided that in doubtful cases it need not be resolved which provision the offender violated so long as he was sentenced to a punishment common to the mooted penal provisions. ${ }^{155}$ The other was

145. IndA Penal Code, supra note 85, at 107 note.

146. See id. See also text accompanying note 35 supra.

147. For a summary of prison terms provided by the Indian Penal Code as later enacted, see 1 W. STOKES, supra note 89, at 25.

148. CODE of CRIMES AND PUNISHMEnts art. 90, reprinted in 2 Livingston Works, supra note 11, at 33; INTRODUCTORY REPORT, reprinted in 1 LIVINGSTON WORKS, supra note 11, at 224-25.

149. INDIA PeNal CoDe, supra note 85 , at $72-73$ note.

150. CODE OF CRIMES AND PUNISHMENTS art. 647, reprinted in 2 LIVINGSTON Works, supra note 11 , at 170 .

151. INDIA Penal CoDe, supra note 85, at 120-21 note.

152. CODE OF CRIMES AND PUNISHMENTS art. 535(4), reprinted in 2 Livingston Works, supra note 11 , at 146.

153. INDIA PeNAL CODE, supra note 85, cl. 297, at 39; id. at 108-09 note.

154. Id. at 119 note.

155. Id. cl. 61, at 7; id. at 78 note. See also Moder Penal Code \$223.1(1) (Proposed Off. Draft, 1962). 
a provision explicitly exempting from punishnient actions technically punishable if the harm caused was "so slight that no person of ordinary sense and temper would complain."158 He reasoned that judges would sensibly exclude such cases in any event, but without the clause could do so only by one of two equally pernicious practices: "by making law, or by wresting the language of law from its plain meaning." 157

I have already lingered longer over Macaulay than the principle of equal time would permit. But the competing principle of doing him justice leads me to stay a moment more in order to try to convey what is perhaps the most remarkable thing about his Code-its freshness of thought and perspicuity of analysis. I have already alluded to his departure froin existing law in making truth a defense to criminal defamation in all cases; ${ }^{158}$ in extending provocation to include verbal insult; ${ }^{\mathbf{1 6 9}} \mathrm{im}$ omitting the crime of adultery; ${ }^{160}$ and in enlarging the privilege to kill in self-defense, ${ }^{101}$ which he accomplished by the daring move of making it enough, as I read it, that the defendant honestly believed that justifying circumstances existed. ${ }^{162}$ To these should be added his treatinent of mens rea questions.

The constructive crimes of felony-murder and misdemeanor-manslaughter found no place in his Code. "It will be admitted," he wrote, "that, when an act is in itself innocent, to punish the person who does it because bad consequences which no lunian wisdom could have foreseen have followed from it would be in the highest degree barbarous and absurd."103 That the same accident occurred while the actor was otherwise committing a crime, say, safely making a fire to burn a will, adds nothing to the offense he committed and punishing him for murder adds nothing to the security of life.

The only good effect which such punishnient can produce will be to deter people from committing any of those offenses which turn

156. India Penat Code, supra note 85, cl, 73, at 9. See also Model Penal Code $\$ 2.12$ (Proposed Off. Draft 1962).

157. INDIA PENAL CODE, supra note 85 , at 81 note.

158. Id. cl. 470, at 64. See also text accompanying note 123 supra.

159. Id. cl. 297, at 39. See also text accompanying note 153 supra.

160. Id. at 131 note. See also text accompanying note 122 supra.

161. Id. cls. 74-84, at 411. See also text accompanying note 97 supra.

162. "Nothing is an offence which is in the exercise of the right of private defense, or which would be an exercise of private defense if the circumstances under which it is done were such as the person who does it behieves in good faith that they are." Id. cl. 84, at 11 . I find myself compelled to read "good faith" in this way for the reasons stated in notes 130 , 131 supra, and because it is not clear how otherwise the self-defense provisions were an enlargement, as Macaulay meant them to be. Another noteworthy feature of the self-defense provisions involves the person who, knowing his life is not imperilled, uses deadly force to protect an interest for which only lesser defensive force is justified (assault, recovering property). His offense is "voluntary culpable homicide in defense" and not murder. INDIN PBNAL CODE, supra note 85 , cl. 299 , at 40.

The chief reason for making this separation is that the law itsolf invites men to the very verge of the crime which we have designated voluntary culpable homicide in defence. ... And it scems difficult to conceive that circumstances which would be a full justification of any violence short of homicide should not be a mitigation of the guilt of homicide.

Id. at 110 note.

163. $I d$. at 111 note in. 
into murders what are in themselves mere accidents. It is in fact an addition to the punishment of those offenses, and it is an addition made in the very worst way . . . that, besides the ordinary punishment, every offender shall run an exceedingly small risk of being hanged. ${ }^{164}$

In these cases, therefore, the offender was punishable only for the offense he committed, with nothing additional for the accidental death. ${ }^{165}$

The use of the constructive-crime theory to raise a crime of negligent killing to murder was, to Macaulay, no more defensible, since it violated a "distinction which inore than any other it behooves the legislator to bear constantly in mind"- that "between harm voluntarily caused and harm involuntarily caused." Negligence often deserved punishment, but it was intolerable "to punish a man whose negligence has produced some evil which he never contemplated as if he had produced the same evil knowingly, and with deliberate malice."168 Thus, where a man negligently killed in the course of committing a crime, he was punishable only for that crime plus the ordinary punishment for negligent killing ("involuntary culpable homicide"). ${ }^{167}$

The same sensitivity to considerations of culpability was manifested in the way Macaulay defined the inental eleinent component of crimes-with unusual particularity and without the confusing epithetical qualifiers not uncommon in the common law. ${ }^{168}$ Strict hability was rarely imposed, and then only where the punishment was minor and the offense regulatory in character. An example is having command of a vessel for hire so loaded as to endanger life. ${ }^{169}$ One knows strict liability was intended because in contiguous clauses Macaulay employed the Code's standard formula for negligence-an act or a manner "so rash or negligent as to indicate a want

164. Id. at 111-12.

165. Id. cis. 294,295 , at 112.

166. Id. at iii-iv.

167. Id. cl. 305, at 112. Macaulay states that Livingston framed his Code on the same principles, id. at 112 note, but I think he was mistaken. CoDE OF CRMMES AND PUNISHMENTS art. 532, reprirted in 2 LIVINGSTON WORKS, supra note 11 , at 144 , provides that the punishment for negligent homicide is to be increased if the act is done in committing an unlawful act-if the unlawful act is a misdemeanor not against the person, the punishment is increased by one-fourth; if the act is an offense against the person, it is to be increased by one-half; if the act is punishable with hard labor, it is to be doubled. Article 597 makes murder any death, accidental or negligent, apparently, resulting from illegal burning. The upshot is that the principle of felony-1nurder and misdemeanor-manslaughter is retained for negligent actions, though not for accidental ones, except in the case of burning. Moreover, article 41 states a broad "lesser-crime" principle that reaches all cases other than homicide: if one in intentionally committing an offense "shall through MISTAKE or ACCDENT, do another act which, if voluntarily done, would be an offense, he shall incur the penalty for the act really done." Livingston was concerned, with reason, that this "is in apparent contradiction to the general other provision, that the will must concur with the act in order to constitute an offense [Art. 27]." CODE OF CRIMES AND PUNISHMENTS art. 41, reprinted in 1 Livingston WORKS, supra note 11 , at $234-35$.

168. Except once, as far as I can find. India Penal Code, supra note 85, cl 257, at 34: "Whoever malignantly or wantouly does any act which he knows to be likely to spread the infection of any disease dangerous to life. ..."

169. Id. cl. 267, at 35 . 
of due regard for human life."170 In other provisions, Macaulay opted for a higher standard of culpability, awareness of the danger, and used language to make this self-evident-selling food "knowing the same to be noxious," 171 or adulterating a drug "intending or knowing it to be likely" that the drug will be dispensed as if not adulterated. ${ }^{172}$ These examples were all regulatory provisions, but it is in this area that law makers are most likely to stumble over mens rea questions. Macaulay displayed the same sensitivity in other portions of the Code. Voluntary culpable homicide occurred when one acted "with the intention of thereby causing, or with the knowledge that he is likely thereby to cause the death of any person." 173 Negligent homicidal liability occurred through an act "so rasl and negligent as to indicate a want of due regard for human life." 174 Mischief was the destruction of another's property "intending thereby to cause wrongful loss to any party." ${ }^{175}$ Making a counterfeit property mark was criminal when done "intending or knowing it to be likely" that the mark may be used as genuine to the injury of another. ${ }^{170}$ The term "fraudulently" was used to denote the mental element for some crimes, ${ }^{177}$ but it was clearly defined in the General Explanations. ${ }^{178}$ It is indeed regrettable that so enlightened and clear-headed an approach to the definition of crimes lad so little effect on later statutory and judicial lawmaking in the criminal law.

Macaulay's Penal Code was adopted in 1860,170 twenty-two years after its submission and one year too late for Macaulay to have lived to see his work bear fruit (though le turned so precipitously and finally from law and codification on his return to England that, by then, he might not have cared). The proposed Code was subjected to revision by several commissions, but lay dormant even after the major revisions were completed.180 Stephen thought the changes improved the original. ${ }^{181} \mathrm{He}$ may, however,

170. E.g., id. cls. $265,266,268$, at 35 .

171. Id. cl. 260 , at 34 .

172. Id. cl 261, at 34 .

173. Id. cl. 294, at 38. Macaulay equates for purposes of punishment acts of intentional killings with those done with knowledge of the likelihood of causing death-both may bo murder. One may quarrel with the choice but one at least knows it is being made.

174. Id. cl. 304 , at 40 .

175. Id. cl. 399 , at 54 .

176. Id. $\mathrm{cl} 456$, at 61 .

177. E.g., id. cls. 253,254 , at 33-34.

178. $I d$. cl. 16 , at 3.

179. Act XLV of 1860,11 India A.I.R. Manuat 947 (2d ed. 1961).

180. The most detailed account of the revisions of Macaulay's draft by subsequent Indian Law Commissions is given in Patra, Historical Introduction to the Indian Penal Code, in INDIAN LAW INSTTTUTE, supra note 85, at 33-46. See also Rankin, supra note 89, at 40-41. Stephen speculates that the long delay

is probably to be accounted for by the extreme aversion which for a long time before the mutiny was felt by influential persons in India to any changes which boldly and definitely replaced native by European institutions. It appeared in every way the safer course to alter and interfere as little as possible .... .

3 J. STEPHEN, stupra note 89 , at 299.

181. He wrote that long delay in its enactment had the beneficial result of providing the opportunity "for a minutely careful revision by a professional lawyer [Sir Peacock Barnes], possessed of as great experience and as much technical knowledge as any man of his time. An ideal code ought to be drawn by a Bacon and settled by a Coke." 3 J. STEPHEN, supra note 89 , at 300 . 
have only been paying tribute to the chief revisor, Sir Peacock Barnes, who sat on the Judicial Committee of the Privy Council at the time Stephen wrote. Omitting the provisions for negligent homicide; ${ }^{\mathbf{1 8 2}}$ reinstating the crime of adultery; ${ }^{183}$ and awkwardly complicating the homicide provisions ${ }^{184}$ were distinctly not improvenents. Still, as Stephen noted, to compare Macanlay's Code with English criminal law was "like comparing cosmos with chaos." ${ }^{185}$ As he later noted: "the Penal Code has triumphantly supported the test of experience for upwards of twenty-one years during which time it has met with a degree of success which can hardly be ascribed to any other statute of anything approaching to the same dimensions." 186

\section{JAMEs FitzJAMES StePhen}

Chronologically, David Field is the next of the codifiers to be considered, but his temporal priority is not great and it will be best to delay crossing the ocean so as not to lose the thread between Macaulay and James Fitzjames Stephen. Stephen, whose 1878 Criminal Code (Indictable Offenses) Bill was said to be the first serious effort in England to codify completely any branch of the law, ${ }^{187}$ was a prominent barrister, essayist, journalist, and judge who was born into and worked among the intellectual aristocracy of Victorian England. His professional career as a barrister was accompanied by outpourings of essays in the intellectual journals of the times through which he participated in the social, moral, and hterary debates of the day. ${ }^{188}$ To the modern generation he is known, if at all, as the Devil's Advocate (pro se, in this case) who, in his book, Liberty, Equality, Fraternity, ventured a sustained rebuttal to the libertarian arguments in John Stuart Mill's Essay on Liberty. ${ }^{189}$ In the tradition of his predecessor codifiers, he was a public servant, having succeeded Sir Henry Maine as law member of the India Supreme Council. Unlike his predecessors, he was a scholar of the criminal law whose three-volume History of the Criminal Law in England still stands as a major contribution.

182. Stephen himself saw to reinserting this provision of Macaulay's Code, cl. 304, when he served as legal member of the Council of India. Id. at 311 .

183. INDIA PEN. CODE $\$ 497$ (1860), reprinted in 1 W. Stokes, supra note 89, at 283.

184. Stephen himself spoke of the enacted Code's homicide provisions as "the weakest part of the Code." $3 \mathrm{~J}$. STEPHEN, supra note 89 , at 313.

185. Stephen, Codification in India and England, 18 Fortnighrux Rev. 644, 654 (1872).

186. $3 \mathrm{~J}$. STRPHEN, supra note 89, at 299. Lord Bryce travelled through India in 1888 and 1889 seeking opinions from competent persons on the Penal Code, as well as the other Indian Codes. The Penal Code received the best press: "The Penal Code was universally approved; and it deserves the praise bestowed on it, for it is one of the noblest monuments of Macaulay's gemius." 1 J. BRYCE, supra note 8, at 108-09.

187. Sir John Holker, Attorney-General, so stated in introducing the Bill. 239 HaNSARD 1938 , quoted in M. LANG, supra note 85 , at 56 .

188. See the bibliography in L. Radzinowicz, Str JAMEs Firzjamies StzPhen (1829-1894) and his Contributions to the Developmenr of Criminal Law 49 (Seldon Soc'y Lecture 1957). I am indebted to Sir Leon for this probing study.

189. Stephen's book was out of print from 1914 until 1967 when the second edition (1874) was republished by the Cambridge Umiversity Press. 
Stephen's active involvement with codification began, like Macaulay's, with his Indian service, although, unlike Macaulay's, it did not cnd with it. As the law member of the Supreme Council, on which he served for over two years (1869-1872), his task was to continue the work of codification in India that had been given a fresh impetus in the aftermath of the Indian Mutiny. ${ }^{100} \mathrm{He}$ took an important role in drafting the Limitation Act and the Contract Act and a determining role in draftimg the Evidence Act. ${ }^{101}$ His work as an Indian codifier drew mixed reviews. Lord Bryce's subsequent interviews with people in India led him to conclude that Stephen's "capacity for the work of drafting was deemed not equal to his fondness for it. He did not shine either in fineness of discrimination or in dehicacy of expression."192 A more recent observer, however, thought that the Evidence Act of 1872 was Stephen's "crowning personal achievement."193

Stephen returned to England with the desire to continue there the codification efforts that had engaged him in India. ${ }^{194}$ An opportunity arose when he was asked to prepare a homicide bill. His draft-the Hormicide Law Amendment Bill of 1874-got to a select committce but not out of it. One ground of opposition that Stephen took seriously was that the Bill codified only a part of the criminal law. Stephen thereupon promptly set himself to "performing, as a private enterprise, the work of making a Digest of it [the criminal law] which might serve as a first step towards a Code."105 Following the appearance of the Digest, he was commissioned, as he had hoped, to prepare a draft code of criminal law and procedure. The Criminal Code (Indictable Offenses) Bill of 1878, his first effort, was not enacted, but it led to the appoimtment of a Royal Commission, composed of Stephen and three High Court judges, which in the following year, 1879, presented a Draft Code (Indictable Offenses) that consisted of a revision of the earher Bill, together with supporting commentary. ${ }^{196}$

Stephen's Code is far more conservative and less ambitious than Macaulay's, and certainly than Livimgston's. At least three major differences in the circumstances of its drafting made that contrast mevitable: the fact that it was written for the developed legal system of late nineteenth-century England; the maturing of the Benthamite codification effort; and the deeply conservative political and moral philosoplyy of its author. ${ }^{197}$

As we have seen, Livingston and Macaulay drafted their codes for jurisdictions whose laws were unsettled, foreign, and hightly rooted. It was far

190. L. Stephen, Life of SiR James FitzjaMes Stephen 248 (1895).

191. $1 \mathrm{~J}$. BRYCE, supra note 8 , at 109; M. LANG, supra note 85 , at 84-85.

192. $1 \mathrm{~J}$. BRYCE, supra note 8 , at 110 .

193. Cahn, Fact-Skepticism: An Unexpected Chapter, 38 N.Y.U.L. Rzv. 1025, 1027 (1963).

194. See Stephen, supra note 185 , at 644.

195. DIGEST OF THE CRIMINAL LAW iv (1877).

196. Report of the Royal Commission Appointed to Consider the LaW Relatina to Indictable Offenses (1879) [hereinafter cited as REPORT], reprinted in 6 PARL. PAP., supra note 116, at 369 .

197. By Stephen's own testimony "by far the greater part both of the Code and of the Report" was his composition. 3 J. STRPHEN, stupra note 89, at 349. 
easier to venture a radical, Benthamite codification in those circumstances than in those prevailing in England in Stephen's time. As Perry Miller has pointed out, one significant function of the codification of a country's laws is to draw a society together by establishing a national identity. ${ }^{198}$ This need was great in Livingston's Louisiana (though, as we have seen, not great enough to carry the day) and equally great in India, where colonial policy (at least in Macaulay's view) was to remake the nation in the image of a modern, Western state. No such need existed for England in Steplen's time. English law was deeply engrained. For all its defects, it worked. Despite what the Benthamite reformers saw as its bizarre and irrational legal system, England had emerged as the leading commercial, industrial, and colonial nation of the world. In these circumstances, mild legal reform in the spirit of even further progress would be a credible enterprise; a root and branch reconstruction of a nation's laws would not. The bulk of the legal profession, lawyers and judges alike, tend, in most conditions, to resist the radical upsetting of legal institutions. Their power of resistance was substantial in Louisiana (enough to win) and in India (enough, with support of a paternalistic colonial policy, to delay for over two decades). In late nineteenthcentury England it was far stronger, in part because of the legal establishment's entrenchment in society and in part because the drive for radical reconstruction of the laws had so inuch less power behind it.

A second and related inajor difference in circumstance was the maturing of the Benthamite codification spirit; inaturing in the sense of growing old, certainly, but also probably in the sense of growing up as well. ${ }^{199}$ Criminal law reform had been a cause in England for decades by the time Stephen returned from India. Even before Macaulay's Indian venture the drive to reform the criminal law of England had begun with the work of Romilly, Bentham's disciple, and others, and had continued with the work of Sir Robert Peel, under whose leadership several statutes were enacted which digested and consolidated a massive number of laws. ${ }^{200}$ These were not the kind of codifications that Bentham had urged ${ }^{201}$ and that Livingston and Macaulay had undertaken, but they established the English tradition of codification to which fresh life was given by the liberalizing electoral changes of the Reform Act of 1832. The following year the India Charter Act was passed, with its provision for Indian codification that eventually led to Macaulay's Indian Penal Code. ${ }^{202}$ In addition, and far more consequential for Englisl reform

198. P. Miller, The Life of the Mind IN America 254 (1965).

199. John Austin, for example, one of Bentham's most powerful disciples, had a more modest view of codification than Bentham did. He did not favor a beau ideal of all possible codes, preferring a code based on existing law; he did not think it important that the average reader be able to understand and know the code's provisions; and he thought the arguments against judge-made law exaggerated. See 2 AUSTIN oN JURISPRUDENCE 620-81 (Lectures 37-39), 1021-39 (Notes on Codification) (5th ed. Campbell 1885).

200. L. RADzINowicz, supra note 8, chs. 15, 16 (1948); Fry, Bentham and English Penal Reform, in JEREMY BENTHAM AND THE LAW, supra note 7, at 34.

201. "Mr. Peel is for consolidation in contradistinction to codification: I for codification in contradistinction to consolidation." 10 BENTHAM Works, supra note 2, at 595.

202. See text accompanying notes 69,70 supra. 
activity, a Royal Commission on Criminal Law was appointed and was charged with digesting the statutory and unwritten criminal law of England and with producing a single comprehensive statute. ${ }^{203}$ Over the next ten years, this and successor Commissions systematically and exhaustively reviewed the substantive and procedural criminal law of England and produced thirteen reports, containing drafts of proposed laws and extensive commentary, ${ }^{204}$ culminating in the production in 1845 of a "Draft of the Bill for consolidating into one statute the written and unwritten law relating to the definition of Crimes and Punishments." 205 This draft was not enacted, nor were later versions of it, nor the parts of it that were introduced in subsequent years. The "stupendous efforts" yielded only the Criminal Consolidation Acts of 1861, relating to offenses against persons and property, which were mild and vague restatements of common-law rules and nothing like a codification, even in the attenuated tradition of a digest and consolidation. ${ }^{200}$

The third inajor factor affecting the conception and nature of the Draft Code was the basic outlook of its draftsnian. Livingston was a radical; Macaulay a Whig. Stephen, by contrast, was a profound conservative in politics and a social Darwinian in morals. ${ }^{207}$ As his brother, Leshe Stephen, put it, "[i]n philosophy le was a disciple of Mill and the utilitarians, ${ }^{208}$ but in the apphication to political questions rather followed Hobbes, and was in sympathy with Carlyle's approval of strong government." ${ }^{200}$ His predilections appeared early. As an eighteen year old he confessed that the 1848 revolutions in Europe excited in him "feelings of zeal against all popular aspirations and in favour of all established institutions." 210 His attack on the ideals of "Liberty, Equality, and Fratermity" was a part of his general anti-democratic thinking, which he expressed with breatltaking dogmatisin and ferocity. The

203. First Rzport of his Majesty's Commissioners on Criminal Law (1834), reprinted in 3 PARL. PAP., supra note 116, at 9.

204. These reports and drafts occupy three volumes of the Irish University Press Series of British Parliamentary Papers (volumes 3, 4, and 5- "Criminal Law") aud cover over 2,000 pages.

205. Fourth Report from Her MAJEsty's CoMmisstongrs fOR REvising aNd CONsoldating the Criminal LaW (1848), reprinted in 5 Parl. Pap., supra note 116, at 414. A Fifth Report in 1849 contained a draft of a criminal procedure bill. 5 PARL. PAP., supra note 116 , at 559 .

206. See L. RADZINOWICZ, supra note 188, at 18; REPORT, supra note 196, at 6, reprinted in 6 PARL. PAP., supra note 196, at 374. A fuller account of the history of these movements for reform is given in M. LANG, supra note 85, at 42-58.

207. The close affinity between his moral thinking and that of Justice Holmes is explored in Mark D. Howe's biography of Holmes. See M.D. HOWE, JUSTICB OLIVER WENDELL, Holmes-The Shaping Years 213, 227-28 (1957), and its sequel, M.D. Howe, The Proving YEARS 171-73 (1963).

208. Stephen acknowledged that in certain areas he was a utilitarian.

That is to say, I think that from the nature of the case, some external standard must always be supplied by which moral rules may be tested; and happiness is the most significant and least misleading word that can be employed for that purpose. . . . I know not on what other footing than that of expediency, generally in a wider or narrower sense, it would be possible to discuss the value of a moral rule or the provisions of a law.

J. STRPHBN, LIBERTY, EQUALITY, Fraternity 227 (White ed. 1967).

209. Stephen, 18 Dict. NAT. Biog. 1051, 1053 (1921).

210. L. STEPHEN, supra note 190, at 107. 
result of dividing political power into bits through universal suffrage and other electoral reforms was "simply that the man who can sweep the greatest of them into one heap will govern the rest. The strongest nnan in some form or other will always rule. ... In a pure democracy the ruling men will be the wire-pullers and their friends. . . ." ${ }^{211} \mathrm{He}$ further believed: "Tlie essence of life is force." 212 "Equality [is] a big name for a small thing" 213 and in America it "tends to invert ... the natural relation between wisdorn and folly," ${ }^{214}$ producing "the rapid production of an immense multitude of commonplace, self-satisfied, and essentially slight people. ..." 215

His rejection of the possibility of any disinterested moral sentiment was profound. "Humamity is only I writ large, and love for Humanity generally means zeal for MY notions." 216 The world was better off with people eschewing grand altruistic pretensions and engaging in their ordinary pursuits. ${ }^{217}$ Since one inan's happiness was another man's unhappiness the principle of greatest happiness as formulated by Bentham and Mill could not be a precept for social action. "A legislator may regard a meat diet as an element of the happiness which he seeks to proinote, but sheep, oxen, and pigs can hardly look on the butcher as a friend." 218 Therefore the utilitarian standard was not overall happiness maximized, but "the widest possible extension of the ideal of life formed by the person who sets up the standard."218 The object of promoting virtue and preventing vice was good and intelligible for legislative purposes ${ }^{220}$ and using compulsion for that object was sound so long as it was likely to be effective at a reasonable cost.221 The purpose of punishing vice when these conditions were met was not only to prevent crime, but to "gratify the feeling of hatred . . . which the contemplation of such conduct excites in healthily constituted minds."222 Indeed, this was true of criminal punishment generally, since it is "highly desirable that criminals should be hated, that the punishment inflicted upon them should be so contrived as to give expression to that hatred, and to justify it so far as the public provision of means for expressing and gratifying a healthy natural sentiment can justify and encourage it." 223

These three circumstances, then-that the Code was meant for Victorian England, that the codification moveinent had inatured, and Stephen's cast of mind-combined to give the Draft Code its character. When Stephen returned froin India resolved to carry on with codifying the English criminal law, it was

211. J. STEPhEN, supra note 208, at 211.

212 Id. at 118 .

213. Id. at 219 .

214. Id. at 212 .

215. Id. at 220 .

216. Id. at 238.

217. J. STEPHEN, ESSAYS BY A BARRISTER 78 (1862) ("Doing Good").

218. J. STEPHEN, supra note 208, at 229.

219. Id. at 228.

220. Id. at 150 .

221. Id. at 144.

222. Id. at 152 .

223. 2 J. STRPHEN, supra note 89 , at 81-82. 
natural for him to see as a preliminary task the creation of a digest of criminal law to serve as the basis for a new code (a task made feasible by the extensive studies of the various Royal Commissions). ${ }^{224}$ In the introduction to his Digest he revealed an approach markedly different from those of Livingston and Macaulay. The Digest was meant to state the existing law by condensing the statutes and articulating the principles of the cases, so that it might serve a "first step" toward a penal code which "must, of course, consist of the existing Criminal Laws of England re-arranged and amended."225 The 1879 Draft Code carried forward that rationale- "the reduction of the criminal law of England, written and unwritten, into one code." ${ }^{220}$ As he later said, a code "ought to be based upon the principle that it aims at nothing more than the reduction to a definite and systematic shape of results obtained and sanctioned by the experience of many centuries."227 Codification aims at eliminating "the needless technicabities, obscurities, and other defects which the experience of its administration has disclosed," but its essential object is "merely the reduction of the existing law to an orderly written system." ${ }^{\text {228 }}$ Changes in the law were also involved, but such changes only as a systematic restatement of the law required.

Stephen's Draft Code, therefore, contaims none of the ground-breaking Benthamism of Livingston's or Macaulay's codes. It dehiberately left untouched a variety of obsolete crimes that would have made Bentham turn in his grave in posthumous disgrace. ${ }^{229}$ The same may be said of his refusal even to deal with the existing law of sedition, ${ }^{230}$ and of his retention of myriads of separate offenses when one generalization would have done. ${ }^{231}$ The Benthamite principle of achieving popular "cognoscibility" disappeared. Stephen said as much, ${ }^{232}$ but it went witlout saying in a Code that stated: "Every one who undertakes to do any act the omission to do which is or may be dangerous to life, is under a legal duty to do that act, and is criminally responsible for the consequences of omitting without lawful excuse to discharge that duty."233

224. India Panal Code, supra note 85 , at $\mathrm{xx}$.

225. J. StePHen, Digest OF THE CRIMINAL LAW Xxiii (1877).

226. RePorT, supra note 196, at 5, reprinted in 6 PARL. PAP., supra note 116, at 373.

227. $3 \mathrm{~J}$. STEPHEN, supra note 89 , at 361 . Bentham's views on this kind of codification, which he pejoratively called consolidation, are exemplified in the following earthy passage from his tract addressed to his "Fellow-Citizens of France on Houses of Peers and Senates," 4 BENTHAM WORKS, supra note 2 , at 419,425 n. a:

Have you a receptacle, the odour of which is troublesome? Employ a set of mennightmen is with us the official name of them-not to empty it, but to look into it, and report, more particularly, how it smells. So doing, you will follow the precedent set by our law-reformers. ....

228. 4 BENTHAM WORRS, supra note 2 , at 350.

229. REPORT, supra note 196, at 12-13, reprinted in 6 PARL. Pap., supra note 116, at 380-81.

230. "On this very delicate subject we do not undertake to suggest any alteration of the law." 6 PARL. PAP., supra note 116, at 388.

231. See, for example, the separate provisions on mischief depending on the object damaged-ships, wrecks, piles and sluices, fish ponds, cattle, hopbinds, telegraphs, etc. Draft Code $\$ \$ 390-407$, reprinted in 6 PARL. PAP., supra note 116, at 516-520.

232. 3 J. STEPHEN, supra note 89 , at 357.

233. Draft Code $\$ 164$, reprinted in 6 ParL. PaP., supra note 116, at 466. 
Stephen did not find law-making by judges, the great Benthamite bête noir, to be a serious problem. Judges had no discretion anyway since they were firmly bound by precedent to the common-law rules. The restatement of common-law rules in statutory form by the Draft Code took nothing from the judges, since they were bound equally by common law as by statutory rules. ${ }^{234}$ The Code did clear up doubts and technicalities, "but," Stephen asserted, "it neither increases nor diminishes to any material extent, if at all, any discretion at present vested in either judges or juries. ${ }^{\text {"235 }}$ Moreover, discretion was sometimes desirable. "Thus for instance," Stephen's Report explained, "it is declared to be a question of law whether a particular order given for the suppression of a riot is 'inanifestly unlawful;' whether the occasion of the sale ... of certain classes of books . . . is such 'as might be for the public good,' and whether there is evidence for the jury of 'excess.' "238 "Blasphemous libel" was inade criminal, ${ }^{237}$ but it was thought "inexpedient to define [it] otherwise than by the use of that expression."238 So also the crime of "obscene libel."233 Common-law offenses were eliminated because parliamentary responsiveness sufficed to deal with newly developed evils, ${ }^{240}$ but all common-law defenses were retamed ${ }^{241}$ - to restate them in statutory terms would lave frozen their sliape since judges would have had to apply thein "according to the[ir] words," while to liave left them as common-law defenses would have kept them fluid because judges would be able to apply them "according to [their] substance."242 (So inucl for lis argument two pages earlier that no greater restraint is imposed upon judges by statutory formulation of common-law rules than by the common-law rules alone!) Further, the Code recognized that a number of situations where defenses might be appropriate simply are not dealt with adequately under the common law and that new rules would have to be created by the judges: "It is far better to decide such cases as and when they arise, and with the light which may then be thrown upon them both by circumstances and by the ingenuity and research of counsel, than to attempt to lay down rules beforehand, for which no definite materials exist." 243

Tle Draft's approach to punishment bore Stephen's mark. Unlike Liv-

234. REPORT, supra note 196, at 7-8, reprinted in 6 PARL. PAP., supra note 116, at 375-76. 235. Id. at 9, reprinted in 6 PARL. PAP., supra note 116, at 377.

236. $I d$.

237. Draft Code $\$ 141$, reprinted in 6 PaRL. PAP., supra note 116 , at 462.

238. ReporT, supra note 196, at 21, reprinted in 6 PARL. PAP., supra note 116, at 389.

239. Draft Code $\$ 147$, reprinted in 6 PARL. PAP., supra note 116, at 463; REPORT, supra note 229, at 22, reprinted in 6 PARL. PAP., supra note 116, at 390.

240. Draft Code $\$ 5$, reprinted in 6 PARt. PAP., supra note 116, at 431; REPORT, supra note 196, at 9-10, reprinted in 6 PaRL. PaP., supra note 116, at 377-78.

241. Draft Code $\$ 19$, reprinted in 6 PARL. PAP., supra note 116, at 435.

242. REPORT, supra note 196, at 10, reprinted in 6 PARL. PAP., supra note 116, at 378.

243. 3 J. STEPHEN, supra note 89 , at 361 . At another point Stephen revealed a different reason for leaving such defenses as necessity or choice of evils unstated: "There is no fear that people will be too ready to obey the ordinary law. There is great fear that they would be too ready to avail themselves of exceptions which they might suppose to apply to their circumstances." Id. at 110. The issue is even today a live one in England. See Williams, Defences of General Application, Necessity, 1978 CRMM. L. Rev. 128. 
ingston, whose Code declared that, "Vengeance is unknown to the law," Stephen regarded vengeance as the central object of criminal punishment. As for capital punishment, it was for him, as Sir Leon Radzinowicz has observed, "the keystone of all moral and penological principles."244 His Code retained the death penalty in all cases in which it was provided for under the existing law. ${ }^{245}$ Stephen later admitted that but for opposing popular sentiment he would have enlarged the mandatory death penalty to include repeating property offenders: "I suspect that a sinall number of executions of professional receivers of stolen goods, habitual cheats, and ingenious forgers ... would do more to check crime than twenty times as many sentences of penal servitude."246 Corporal punishment, in the form of flogging and whipping was retained, ${ }^{247}$ Stephen's only criticism of existing law being that it was not severe enough-"little, if at all, more serious than a birching at a public school."248 Finally, Stephen's major reason for urging his Code was characteristic. It was not that crime was rampant. He thought it had been more active and mischievous at other times and places. What struck him was that

there has never been an age of the vorld in which so much and such genuine doubt was felt as to the other sanctions on which morahity exists. ... . In such circumstances it seenis to be specially necessary for those who do care for morality to make its one unquestionable, indisputable sanction as clear, and strong, and emphatic, as words and acts can make it. ${ }^{248}$

It would, however, be misleading and unjust to leave these comments on Stephen's Code at that. Within the codification tradition in which he worked, the Code was a significant achievement. His Code was to the English criminal law as- to paraphrase what he said of Macaulay's Code-cosmos to chaos. It drew together, systenatized and pruned the Enghish law, not radically but still not trivially, and made of it a nore manageable whole. Just to advert, by way of example, to some of the niany useful features of the code: it adopted from the Indian Penal Code Macaulay's provision for dismissal of de minimis cases; ${ }^{250}$ abohished the distinction between felonies and misdemeanors for purposes of determining a variety of procedural consequences; $;^{261}$

244. L. RADziNowicz, supra note 188 , at 35.

245. Draft Code $\$ 178$ (murder), reprinted in 6 PARL. PAP., supra note 116, at 469; id $\$ 75$ (treason), reprinted in 6 PARL. PAP., supra note 116, at 445; id. \$106 (piracy with violence), reprinted in 6 PARL. PAP., supra note 116, at 454; id $\$ 81$ (burning ship of war or government arsenals), reprinted in 6 PARL. PAP., supra note 116, at 447.

246. $1 \mathrm{~J}$. STRPHEN, supra note 89 , at 479.

247. Draft Code $\$ 10$, reprinted in 6 PARL. PAP., supra note 116, at 433.

248. 2 J. STRPHEN, supra note 89 , at 92.

249. 3 id. at 367 . Stephen had come far from Bentham who regarded the pronouncement of moral guilt as beyond the competence of and therefore imappropriate to the criminal law. See Fry, supra note 200, at 20, 26-27. The contrast with Macaulay is also great. See note 134 supra.

250. Draft Code $\$ 13$, reprinted in 6 PARL. PAP., supra note 116, at 433.

251. RePoRT, supra note 196, at 14, reprinted in 6 PARL. PAP., supra note 116, at 382. 
precluded mandatory minimum punishments; ${ }^{252}$ eliminated the requirement of materiality in perjury; ${ }^{253}$ tried to articulate the situations in which homicidal omissions were culpable; ${ }^{254}$ formulated the law of murder without the common-law concepts of malice aforethought and implied malice; ${ }^{255}$ narrowed felony-murder to cases where the defendant either did an unlawful act that he should have known would be likely to cause death, or intentionally inflicted great bodily injury in the commission of designated heinous felonies; ${ }^{256}$ established imsult as a possible legal provocation;257 made an illegal arrest only evidence of provocation rather than an automatic basis for reducing the offense to nuanslaughter; ${ }^{258}$ eliminated the defense of impossibility in attenupt; ${ }^{259}$ provided for the punishment of non-homicidal neghigent injuries; ${ }^{280}$ allowed the privilege of self-defense even where the victim's aggressive acts imitiated the encounter; ${ }^{261}$ and eliminated the distinction between second degree principals and accessories before the fact. ${ }^{262}$

To be sure, even as a techmical document the Code had limitations. For example, as one of its strategies for meeting the danger of mistakes, it made the unfortunate move of turning the criminality of conduct into a gamble for the actor. So in dealing with killing in defense of dwelling, if the killing took place in the nighttime, the Code made it a defense that the accused reasonably beheved the victim to be a criminal intruder and that his action was necessary to stop him, ${ }^{263}$ but in the daytime a defense was made out only if the action was in fact necessary for the purpose. ${ }^{264}$ More generally, the Draft stopped short of generalizing where, at least from today's perspective, ${ }^{265}$ generalization would have been desirable. For example, Stephen retained the dozen or so separate provisions on mischief to different kinds of property ${ }^{266}$ and the numerous separate specifications of the crime of theft depending on the object stolen - wills, ${ }^{267}$ post letter bags, ${ }^{268}$ post letters, ${ }^{269}$ cattle, ${ }^{270}$ and so on. Further illustrations were his unwillingness to generalize a defense of

252. Draft Code $\S 12$, reprinted in 6 PARL. PAP., supra note 116, at 433.

253. Id. $\$ 119$, reprinted in 6 PARL. PaP., supra note 116 , at 457.

254. Id. pt. 15, reprinted in 6 PARL. PAP., supra note 116 , at 463.

255. Id. \$\$ 174, 175, reprinted in 6 PARL. PAP., supra note 116, at 468.

256. Id. $\$ 174(\mathrm{~d}), 175$ (a), reprinted in 6 PARL. PAP., supra note 116, at 468.

257. Id. 1176 , reprinted in 6 PARL. PAP., supra note 116, at 468.

258. $I d$.

259. Id. \$74, reprinted in 6 PARL. PaP., supra note 116, at 445.

260. Id. \$201, reprinted in 6 PARL. PAP., supra note 116, at 474.

261. Id. $\$ 56$, reprinted in 6 PARL. PAP., supra note 116 , at 441.

262. Id. \$ 71, reprinted in 6 PARL. PAP., supra note 116, at 444.

263. Id. \$ 62, reprinted in 6 PARE. PAP., supra note 116 , at 442.

264. Id. \$61, reprinted in 6 PARL. PAP., supra note 116, at 442. He makes the same move in defining bigamy. Id. \$216, reprinted in 6 PARL. PAP., supra note 116, at 477.

265. Sir Leon Radzinowicz's kinder judgment may be fairer: "By extracting principles out of the 'endless myriad of precedents' and 'wilderness of single instances', he raised the status of criminal law as a legal discipline in a most remarkable way." L. RADzINowicz, supra note 188 , at 22.

266. See note 231 supra.

267. Draft Code $\$ 254$, reprinted in 6 PARL. PaP., supra note 116 , at 485.

268. Id. \$255, reprinted in 6 PARL. PAP., supra note 116 , at 485 .

269. Id. $\$ 256$, reprinted in 6 PARL. PAP., supra note 116, at 486 .

270. Id. $\$ 260$, reprinted in 6 PARL. PAP., supra note 116 , at 486. 
necessity; ${ }^{271}$ and his treatment of omission and causation solely by specifying particular instances. ${ }^{272}$

Still, as Sir Leon Radzinowicz has said, ${ }^{273}$ Stephen's Draft Code was a significant advance. Undoubtedly, had Parliament enacted his code, generations of lawyers and students might have been spared a huge corpus of tortured case law, and the judges might have found more useful outlets for their analytical ingenuity. In any event, Parliament did not pass it. Given the strong conservative influences of the period, so large a piece of criminal law reform was too much for Parliament to bite off and too important to be swallowed whole. ${ }^{274}$ But despite its failure in England, the Code had a fair measure of success in other Commonwealth countries. The Draft Code served as $\dot{a}$ model for a number of newer jurisdictions, imcluding New Zealand, ${ }^{276}$ Western Austrahia, Queensland and Tasmania, ${ }^{276}$ and Canada, ${ }^{277}$ for which the chaos of the common law of crimes was less of an old shoe than it was for the English.

\section{DAVID Dudley Field}

Bentham, our first penal law codifier, never drafted a code. David Dudley Field, our last, never drafted a penal code. His dominance of the New York codification efforts is not in doubt. ${ }^{278}$ But the first report of the Commission that eventually produced the substantive Field Codes states that the Penal Code was being prepared by another of the Commissioners, Curtis Noyes, a former district attorney. ${ }^{279}$ This represented a plausible division of labor since Field had no professional or scholarly competence in the criminal law and had been assigned the hon's share of the burden-drafting, the Civil and Potitical Codes. ${ }^{280}$ Moreover, Field's biographer, his brother, not otherwise given to minimizing his subject's activities, tells us quite explicitly that Noyes prepared the preliminary analysis of the Penal Code and then drafted the Code itself with the assistance of B. V. Abbott. ${ }^{281}$ None-

271. See note 243 supra. He might have yielded here to the wisdom of his colleagues since he did draft a necessity provision in his Digest of the Criminal Law (art. 32).

272. Draft Code $\$ \S 159-164,170-173$, reprinted in 6 PARL. PAP., supra note 116, at 465-66, 467-68.

273. Stephen "remains the greatest draftsman and codifier of criminal law this country has ever produced, a worthy peer of the most prominent amongst Continental lavryers who have left their mark in this field." $\mathcal{L}$. RADZINowicz, supra note 188, at 22.

274. See M. LaNG, supra note 85 , at 56-58.

275. The Criminal Code Act, 1893, is a very close copy. 57 Vict., c. 56 (N.Z.).

276. Sir Saunuel Griffths produced a code for Queensland, heavily based on the Stephen Code, which, in turn, was borrowed in the other jurisdictions. See P. Bretr \& P. WallzR, Craminal Law 4 (4th ed. 1978).

277. See J. Crankshaw, Crankshaw's Crmminal Code of Canada xv (6th ed. 1935).

278. Hicks, David Dudley Field, in 6 Dicr. of AMER. BIoG. 360, 362 (1943).

279. FIRST RRPORT OF THE COMMISSIONERS OF THE CODE (1858), cited in Reppy, The Field Codification Concept, in David Dudlex Field Centenary Essays 17, 40 (A. Reppy ed. 1949) [hereinafter cited as Fueld Essays]. See also Moore, Wm. Curtis Noyes, in 13 Dicr. OF AMER. BIOG. 592 (1943).

280. Reppy, supra note 279 , at 40.

281. H. Field, ThB LifB of Dayd Dudley Field 78, 81 (1898). 
theless, Field was one member of the small group of three that produced the Penal Code ${ }^{282}$ and his intellectual domination of the codification effort in New York was unquestionable. For present purposes, therefore, the Penal Code may be taken, as it is generally, as one of the Field Codes.

Field was one of a notable family of men of achievement in mineteenthcentury America. His brother, Stephen, became Chief Justice of the Supreme Court of California and later a Justice of the United States Supreme Court. Another brother, Cyrus, was a successful entrepreneur who had nuch to do with laying the first trans-Atlantic cable. David Dudley Field had a prominent career at the bar in New York, but he is remembered today because of his singular devotion to the cause of reforming the administration of justice through the codification of the laws, which he pursued as an unpaid public service for most of his life. ${ }^{283}$

Field was the dominant figure in the movement for codification of American law that spanned approximately the middle fifty years of the nineteenth century. Livingston was the major figure at its inception. Field presided over its rise and modest successes and witnessed its ultimate decline. ${ }^{284} \mathrm{~A}$ number of more fundamental and related controversies of the period became involved in the great codification controversy. There was, first, the rise of populisin associated with Jacksoman democracy, a movement which, at its imception, seized upon Benthamite iconoclasm for its basic orientation in matters of law. ${ }^{285}$ In their contest with the Federalists and the Whigs, the Jacksonian Democrats advanced the causes of the producing classes-farmers and workingmen-against the business community, especially monopoly capitakisn; of individual human rights against property rights; of greater equality in the distribution of wealth; of popular political participation in all phases of government against aristocratic privilege. ${ }^{286}$ Codification, then, was a natural battleground for these ideas, for it represented an attack on the power of lawyers and judges to make and declare law without democratic participation. It offered a plainly articulated body of laws accessible to and understandable by all in place of the oracular, mysterious incantation of

282. See Field, Address to the Law Reform Society (1883), reprinted in 2 DaVID DUDLEX Firld, Spezchrs, Arguments and Miscellaneous Papers 476, 480 (Sprague ed. 1884) [hereinafter cited as FIELD SPEECHES]: "Night after might the commissioner met at each other's houses and re-examined carefully every section, every line, and every word [of the Penal Code Draft]."

283. His only pohitical office was Congressman from New York to which he was appointed to fill the remaining two months of the term of the resigned incumbent. RECORD OF THB LIFB of DaVID Dudley FiEld 45 (E. Field ed. 1931).

284. Roscoe Pound was of the view that Field's codification efforts might have changed the whole course of American law if they had come a quarter century earher when the law was still in its formative stage. Pound, David Dudley Field: An Appraisal, in FirLd Essays, supra note 279 , at 5,16 (1949).

285. As we saw earlier, see text accompanying notes $42-63$ supra, Livingston, a friend and counsellor of Jackson, who served in his administration, early represented the legal side of Jacksonian sentiment. Bentham himself was lionized by the Jacksonian Democrats. He was toasted at a Democratic Fourth of July celebration in 1835 as "the modern apostle of liberty and reform. . . [M] ay every democrat and workingman remember that he has most happily combined the essence of their principles in one short line- The greatest good of the greatest number.' " A. Schlesngere, JR., The AGE OF JACRSON 330-31 (1945).

286. See A. Schlesinger, JR, supra note 285 , ch. 24. 
doctrinal technicalities by lawyers and judges. And it placed the power over the law squarely in the hands of the people's elected representatives in the legislature.

Another controversy, related to the first but more rarefied, was the controversy between positivism and historicism in accounting for the shape of law. In this controversy Field was the leader of the Benthamite cause. ${ }^{287}$ His most articulate challenger was another New York lawyer, James Carter, who, as a disciple of the Savigny school flourishing in Germany, ${ }^{288}$ provided a theoretical basis for resistance to codification as well as to innovative legislation generally. Carter argued that law could not be produced new and whole by legislative fiat because law reflects the experience and life of a culture, which projects a social standard of what is right. The discovery and explication of the precepts and primciples constituting this standard required the ministrations of a professional class of lawyers and judges employing the method of juristic science in the processes of litigation and decision. ${ }^{280}$ These doctrines have long simce ceased to be influential in American jurisprudence, but in Field's day they constituted a serious challenge to codification. ${ }^{200}$

A third, more basic, issue involved in the codification controversy, as Perry Miller has pointed out, was the "contest between nationalism and cosmopolitanism"- provincial codifiers versus the cosinopolitan adherents of the common law. ${ }^{201}$ As against the judges and lawyers who worked with the materials and in the traditions of the English common law, the codifiers offered an opportunity for the virtually instantaneous creation of an American body of law, responsive to purely American circumstances and sentiments.

Field's entrance into the center of the storm coincided with the ascendancy of Jacksomian populism in New York. Reflecting a revulsion against lawyers and judges, a Constitutional Convention in New York in 1846 leveled the existing court structure, established elective judges with limited tenure and entitled any male over twenty-one years of age of good character

287. See his arguments in 3 FIELD SPEeches, supra note 282, at 239, 411.

288. F. von Savignx, Of the Vocation of OUR AGE for Legislation and JURisprudBnce (1831 ed. A. Hayward trans). See E. Patterson, JuRISPRudence: Men and Idgas of the Law 421-24 (1953).

289. J. Carter, The Proposed Codffication of Our Common Law (1884). Carter's objections, however, did not extend to codifying the criminal law. Id. at 14-18, 76.

290. R. Pound, supra note 284, at 7.

Professor George Fletcher is one of the few contemporary scholars who lean in this direction. See, e.g., Fletcher The Right Deed for the Wrong Reason: A Reply to Mr. Robinson, 23 U.C.L.A. L. Rev. 293, 294 (1975), where he praises Robinson, A Theory of Justification: Societal Harm as a Prerequisite for Criminal Liability, 23 U.C.L.A. L. REv. 266 (1975), in terms that evoke the historical school. Robinson

does not claim that his position efficiently furthers any or all aims of the criminal law. Rather he starts from a construction of the criminal law as a received set of principles that ought to be binding on our deliberations when conduct should be punished. The authority for these principles is not their instrumental value, but their grounding in a theory of just punishment implicit in the patterns of liability that have accrued in the common lav.

See also Fletcher, The Metamorphosis of Larceny, 89 Harv. L. Rev. 469 (1976).

291. P. MIILER, supra note 198 , at $244,255$. 
and in possession of the requisite learning and ability to be admitted to the bar. ${ }^{202}$ In substantial measure due to Field's pamphleteering, ${ }^{293}$ it also directed the legislature to appoint two commissions, each with three commissioners, one to propose reforms in the law of practice and proceedings, ${ }^{204}$ and the other "to reduce into a written and systematic code the whole body of the law of this State," specifying such changes they thought proper. ${ }^{295}$ This led to the appointment of the Commissioners of Practice and Pleading and the Commissioners of the Code in 1847. Field was shortly thereafter made a member of the former Commission and in that capacity did the pioneering work on procedural reform ${ }^{296}$ that resulted in the Field Code of Procedure. ${ }^{297}$ The latter Commission, on which Field did not serve at first, made little progress, producing only a limited statutory revision, until a newly created Commission of the Code, with Field as one of the three Commissioners, was established by statute (drafted by Field) in $1857 .{ }^{298}$ It was this Commission that produced drafts of the famous substantive Field Codes-a Political Code, a Civil Code, and a Penal Code, ${ }^{209}$ the last in 1864 and again in 1865, after recoinmendations of the judges, prosecutors and others had been taken into account. $^{300}$

The Field Penal Code ${ }^{301}$ gives no evidence of a radical, Livingstonian spirit at work, any more than do the other Field Codes. Though his codes may have "represented the culmination of the Jacksonian demand for reform," ${ }^{02}$ Field's demands for reform were less fundamental. He was, after all, despite occasional radical rhetoric, ${ }^{303}$ an establishment New York lawyer all his life. ${ }^{304}$ His views on property rights were in the correct conservative tradition ${ }^{305}$ and his views on the training of lawyers were

292. N.Y. ConsT. of 1846, art. VI, $\S \S 2,4,8,12$ (F. Hough ed. 1867) (annotated).

See C. WARREN, A HISTORY OF THR AMERTCAN BAR 532 (1911).

293. M. LANG, supra note 85, at 118; Pound, supra note 284 , at 9.

294. N.Y. CoNST. OF 1846, art. VI, § 24 (F. Hough ed. 1867).

295. Id. art. I, § 17.

296. See Reppy, supra note 279, at 30-36. $55,56$.

297. See Clark, Code Pleading and Practice Today, in Freld Essays, supra note 279, at

298. H. FIRLD, supra note 281, at 74; M. LANG, supra note 85 , at 132-36.

299. See Reppy, supra note 279 , at 36-42.

300. Commissioners of thi CODE, DRAFt of a Penat Code for New York (1864); Commissioners of the Code, The Penal Code of the State of NeW York (1865) (reported complete).

301. I will be considering primarily the 1864 draft. The 1865 version differs little from the earlier draft.

302. A. SCHLESINGER, supra note 285 , at 33.

303. P. MILLER, supra note 198 , at 260.

304. A curious shade on his legal career arose over his representation, and alleged participation in some of the questionable deals of Jay Gould, Jim Fisk, and "Boss" Tweed in connection with Erie Railroad activities. See C. AdaMs \& H. AdAMs, Chapters of ERIB 36, 134, 183 (1956); Hicks, David Dudley Field, in 6 DiCr. AMER. Brog. 360-62 (1931). The evidence of serious improprieties is great, although lawyer's ethics at the time were in flux and judging by the standards of another day may be unfair. See Schudson, Public, Private, and Professional Lives: The Correspondence of David Dudley Field and Samuel Bowles, 21 AM. J. LEGAL HIST. 191 (1977). In any event, though a combination of public spirit and private improbity is always unexpected, it is hardly unknown. See, e.g., F. OWEN, TEMPESTUOUS JOURNEY: LLOYD GBORGB, HIS LIFE AND TIMES 225-40, 628, 686-93 (1955); 2 C. FUESS, DANLEL WEBSTER 389-94 (1930).

305. See P. MILLER, supra note 198, at 259. 
certainly not populist. He deplored loose apprentice systems as perpetuating "transcriber[s] of legal formulas" and "promotor[s] of neighborhood litigation"; he felt that a good lawyer must be learned in the wholeness of the law and the relationship of its parts, ${ }^{300}$ and that strict examinations following a prescribed course of study in school or office should precede admission to the profession. ${ }^{307}$ Field's paranount concerns were those of the professional lawyer, not radical reform of the law or broad social reform generally. ${ }^{308}$ In particular, the outpouring of judicial decisions was becoming an unmanageable avalanche. The "wilderness of single instances" of which "the lawless science of our law" consisted, called for one remedy: "It is to reduce the bulk, clear out the refuse, condense and arrange the residuum, so that the people, and the lawyer and judge as well, may know what they have to practice and obey." ${ }^{309}$ He meant his Penal Code as a remedy of this kind.

Field's Code yields little joy or instruction to the contemporary reader. Livingston's Code had passion and originality; Macaulay's had perspicuity and style; and Stephen's had high professional competence. Bnt Field's is plain pedestrian. That quality is not among the profession's cardinal sins. But what makes its presence in the Code so painful is the sense that one has discovered the headwaters of a tradition that dominated criminal law-making until fairly recent times. That sense is heightened as one recognizes in many of its provisions the baleful prototypes of formulations that have burdened American criminal law for generations: murder by "any act imminently dangerous to others and evincing a depraved mind, regardless of human life," 310 or "[w]hen perpetrated without any design to effect death, by a person engaged in the commission of any felony"; ${ }^{311}$ conspiracy "to commit any act injurious to the public health, to public morals, or to trade or commerce, or for the perversion or obstruction of justice ..."; ${ }^{312}$ excusable homicide "[w] $[$ hen committed by accident and misfortune in the heat of passion, upon any sudden and sufficient provocation, or upon a sudden combat." 313

306. Id.

307. Field, Judicial Delays: Second Report to the American Bar Association, in 3 FreiD SPEECHES, supra note 282, at 199, 225. See also Field's 1889 address where, though late in his career, he observed: "[O]ur profession is one of the great conservative forces of society; ... it forms a group around the judges, serving the double purpose of oversight and defense. ... In the incessant conflict between law and lawlessness, an immense majority of lawyers have always stood on the side of law." The True Lawyer, in 3 Firld SPEECHES, supra note 282 , at 399,402 .

308. See H. Field, supra note 281, at 73-74. (His ambition "was not to be a breaker of the precious traditions of the past. He had no purpose or desire to destroy the Common Law, but to preserve it and exalt it by cutting off its excrescences, and by translating it into the language of the people. ....").

309. Address by $\mathrm{D}$. Field at the New York University Law School (April 7, 1884), reprinted in 2 FIEZD SPEECHES, supra note 282, at 503, 509. (1864).

310. Commissioners of the CODE, DRAFt of a Penal CodB for New York \$241(2)

311. Id. \$241(3).

312. Id. § $224(5)$.

313. Id. § 260 (2). 
One major defect of the Code arose from what the Commissioners identified as its first objective: "To bring within the compass of a single volume the whole body of the law of crimes and punishment in force within this state"-in short, to produce a coinprehensive compilation of existing law. ${ }^{314}$ Although the terms of the Act creating Field's Commission ${ }^{315}$ seemed to require as much, it is also true that he was the draftsman of this statute, which, we are told, he drew up "with the greatest care." ${ }^{16}$ Moreover, there are ways of approaching restrictions in the terms of a commission. Macaulay, as we have seen, found reason to go well beyond the terms of his. And even Stephen managed a number of important improvements in English law in the course of consolidating it. Field and Noyes were apparently content with their bonds, whether out of conviction or political necessity one cannot be sure.

The objective of encompassing all actions carrying a criminal punishinent was carried through with unremitting thoroughness. The Code drew within its scope every instance in which a New York statute imposed the criminal penalty-and by 1864 , that penalty was well on its way to becoming the major regulatory sanction. So one finds included such subjects as intoxicated physicians, ${ }^{317}$ overloading passenger vessels, ${ }^{318}$ mismanagement of steamboats, ${ }^{319}$ trade mark infringements, ${ }^{320}$ refilling mineral bottles, ${ }^{321}$ omitting to mark packages of hay, ${ }^{322}$ running ferries without authorization, ${ }^{323}$ using nets unlawfully in the Hudson River, ${ }^{324}$ misconduct by auctioneers, ${ }^{325}$ and removing beacons in New York harbor. ${ }^{326}$ Even Stephen, faced with a similar charge, omitted provisions of this genre from his Code on the ground that they are "so closely connected with branches of law whicl have little or nothing to do with crimes, commonly so called, that it seems better to let thein stand as a class than to introduce them into a Criminal Code."827 Field's Code, on the other hand, carrying the spirit of codification to its ultimate conclusion, saw "[t]he value of the Penal Code" as depending "upon its containing provisions which embrace every species of act or omission which is the subject of criminal punishment."328

Related to this regrettable choice is the decision to retain in separate provisions the variety of crimes that had emanated separately from the ad

314. Id. preliminary note, at iii.

315. Ch. 26, 1857 N.Y. Laws.

316. H. FIELD, supra note 281, at 74.

317. Commissioners of the Code, Draft of a Penal Code for New York $\S 404$ (1864).

318. $I d$. $\$ 406$.

319. $I d$. $\$ 408$.

320. Id. \$\$ 410-414.

321. Id. $\$ 417$.

322. $I d . \$ 449$.

323. Id. $\$ 459$.

324. Id. \$ 467.

325. Id. $\$ \$ 503-510$.

326. Id. § 713 .

327. REPORT, supra note 196, at 12, reprinted in 6 PARL. PAP., supra note 116 , at 380.

328. Commissioners of the CODB, DRAFT OF a PeNaI CODB for NeW YORK iv (1864), (preliminary notes). 
hoc legislative process. The draftsmen themselves recognized this, pointing out that "the bulk of the Code may be materially reduced without impairing its clearness and efficiency, by a rigid exclusion of particular provisions which are capable of being combined im general ones. . . ." ${ }^{220}$ But caution led them to defer to legislative revision to accomplish this with the result that the Code, even more than Stephen's, looks more like a hoarder's accumulation than a code, or even a consolidation.

Regarding the crimes "commonly so called," the tendency was to reproduce existing statutes virtually whole. There was some effort "[t]o supply deficiencies and correct errors in existing definitions of crimes," one of the Commission's stated goals. ${ }^{330}$ For example, noting that the many special statutes governing perjury in a variety of proceedings were unnecessary in view of the general perjury statute, which abancloned the common-law restriction to judicial proceedings, the draftsinan omitted the unnecessary statutes..$^{331}$ But the examples of such revision were few and usually no more daring. ${ }^{332}$ Indeed, when changes were made they were often misconceived. Though degrees of murder had been introduced precisely to allow juries to withhold capital punishment, the Code eliminated them on the ground that "[t]he practical result of introducing such a distinction will be that jurors influenced by unwillingness to unite in a capital conviction, will always find the prisoner guilty of the second degree only."333 While provocation properly conceived serves to reduce an intentional killing to manslaughter, ${ }^{334}$ the Code made it serve to reduce an unintentional killing to manslaughter ${ }^{335}$ and to contribute to excusing an accidental killing. ${ }^{336}$

Consistent with one of the fundamental tenets of codification, the Code eliminated common-law offenses ${ }^{337}$ on the ground that "[a]s long as the criminality of acts is left to depend upon the uncertain definition or conflicting authorities of the common law, uncertainty must pervade our criminal jurisprudence." ${ }^{338}$ Similarly, common-law terms were avoided, "because it is deeined essential to the usefulness of the Code that its definitions should not be dependent upon a recourse to the common law to render them intelligible." ${ }^{339}$ Yet in defining some important crimes the Code invited back precisely what it purported to eliminate. Larceny, for example, was minimally defined as "the taking of personal property accomplished by fraud or stealth, and with intent to deprive another thereof." 340 The Note then identified the

329. Id. at vi.

330. $I d$. at iv.

331. Id. $\$ 150$ note.

332. See, e.g., id., $\$ 319$ (tightening the law of zape), 131 (spelling out the five ways of improperly infuencing a juror).

333. 1 d. $\$ 241$ note.

334. See Draft Code § 176, reprinted in 6 PARL. PAP., supra note 116 , at 468. (1864).

335. COMmisstoners of THE CODB, DRAFT OF A PENAL CODE FOR NBW YORK $\$ \$ 248,252$

336. Id. $\$ 260(2)$.

337. $I d$. 2 .

338. Id. at iv.

339. Id. $\$ 248$ note.

340 . Id. § 584 . 
issues that had produced the most difficulties: "[w]hat property may be the subject of larceny"; "[w] hat is an intent to deprive another of his interest in the property taken"; "the distinction between a taking originally, and which is therefore larceny, and a possession acquired without intent to steal, and followed by a wrongful appropriation ...." But instead of legislating solutions to these problems, the Note in each instance simply directed the reader to the scores of English and American cases responsible for the chaos. ${ }^{341}$ Similarly, in dealing with burglary, the Note explained that "[i]t lias not been thought best to insert any definition of 'breaking' or of 'entering', but rather to leave the meanings of these words, now well settled [sic], to adjudication" and then cited over thirty-five English and American cases. ${ }^{342}$ In the Field Code, the codification spirit had not simply matured, it had died. Having begun with Bentham as, in Sir Arthur Maine's phrase, "the clearing of the brain," ${ }^{443}$ it became at the end a rearranging of the attic.

It is remarkable that so tame a treatment of the existing law should have aroused the opposition it did. It may have been the victim of the heavy lawyer resentments generated by Field's other codes and by his many caustic attacks on the bar. ${ }^{344}$ Submitted to the New York legislature in 1865, it was not enacted until $1881,{ }^{345}$ an earlier enactment having been blocked several times by failure of passage in one house or the other or by gubernatorial veto when passed by both. ${ }^{346}$ The Draft Code, either directly or indirectly through the New York Penal Code, which substantially enacted it, had a remarkable influence on American law, ${ }^{347}$ taking root, as did Stephen's Code, in recently established jurisdictions. It was enacted in Dakota in $1865^{348}$ and in California in $1872,{ }^{349}$ where the local Commissioners further injured an already marred product by reintroducing the concepts of malice aforethought and express and imphed inalice in the homicide provisions. ${ }^{350}$ Both states enacted the other Field Codes as well. ${ }^{351}$ California's adoption of the Penal Code was significant in the further success of the Code in a number of other

341. Id. note.

342. $I d . \$ 540$ note.

343. J. DilloN, supra note 10 , at 316.

344. See Beckman, supra note 65 , at $148,172$.

345. Ch. 676, 1881 N.Y. Laws, I, 913.

346. See M. Lang, supra note 85 , at 146.

347. Id. at 152-59.

348. Preface to N. DaK. Rev. CODE iv (1895).

349. Cal. Penal Code (1872) 3 Appendix to Journals of the Senate and Assembiy, 19th Sess. 316, 349 (1872).

350. See Proposed Cal. Revised laws, Penal Code $\$ 187,188$ (1870),

351. Some credit for Field's success in California apparently belongs to his brother, Stephen J. Field, who stated in his Reminiscences that as a California state assemblyman in 1851 he adapted to California circumstances and helped secure the passage of the civil and criminal practice codes his brother had proposed for New York. C. Swisher, STzPHEN J. FirLd, CRAFISMaN of THR LaW 54-55 (1930). Later, while a Justice of the United States Supreme Court in 1873, he served, remarkably, on a committee of code examiners, appointed by the Governor of California, to re-examine the political, civil, penal and civil procedure codes enacted earher and to propose amendments. See THE CODE ExAMINER's Notrs FROM Draft of an Act to AMEND the Civi Code 3, 11 (M. Dodge ed. 1916). 
Western states-Arizona, ${ }^{352}$ Idaho, ${ }^{363}$ Montana, ${ }^{854}$ Oregon, ${ }^{355}$ Utah ${ }^{356}$ and Wyoming ${ }^{357}$ - where the California model was influential. None of the codes we have considered had a larger measure of influence. None deserved it less.

\section{Conclusion-Wechsler and the Model Penal Code}

Between the Field Penal Code and the first stirrings of criminal law reform by the American Law Institute before World War II there is a yawning emptiness. Those stirrings, however, led eventually, under the leadership of Herbert Wechsler, to the Model Penal Code, and it is appropriate to conclude this piece with a few comments on that Code viewed from the perspective of this account of its predecessors.

By the time the idea of a Model Penal Code emerged, the codification controversy of the nineteenth century was over. The legislatures had long since asserted their dommance as lawmakers, though through statutes in particular areas, rather than through comprehensive codes, which the increasing complexity of law rendered quite futile. Since the role of courts in common-law adjudication and statutory interpretation had been settled as subordinate, curbing an arrogant judiciary no longer figured as the driving reason for legislation. ${ }^{358}$ Gone also were such codification aspirations as writing the law so simply that any citizen could read and understand all his rights and obligations. The Benthamite precept-"every man his own lawyer"-had become quaint.

Much of this was true by the time of Field's and Stephen's codes and one finds no rekindling of the old codification flames in the Model Penal Code. But the similarity ends there. For what is most notable in Professor Wechsler's Model Penal Code enterprise is its affinity with the fundamental reformist zeal of the early Benthamite codification movement. Moving the principal lawmaking power to the legislature was not, after all, the simple cure that the early codifiers imagined it would be. Though many states had adopted criminal codes and virtually all had adopted substantial bodies of statutory law, the law represented in these statutes was scarcely less entitled to the Benthamite scorn than was the common law. As Professor Wechsler observed early in the work of the Model Penal Code, "[a]s our statutes stand at present, they are disorganized and often accidental in their coverage, a medley of enactment and of common law, far more important in their gloss than in their text even in cases where the text is fairly full, a combination of

352. See Preface to Ariz. Penat Code, Artz. Rev. Stat. (1913).

353. Idaho Rev. Stat. pt. 4 (Penal) (1887). Idaho Code $\$ 18$ (Crimes and Punishment), comp. Ieg. notes (1940).

354. Montana Penal Code (1895); see H. Field, supra note 281, at 91.

355. 3 OREgon CoMpInd LAWS ANNor. Code, comp. leg. notes (1940).

356. UTAB Code ANN. \& 76 (Penal Code), historical notes (1953).

357. 1890 WYo. Sess. Laws, ch. 73.

358. The contest between legislatures and courts over which should govern reappeared, of course, in the bitter controversy over judicial revievr. 
the old and of the new that only history explains." ${ }^{359}$ To this challenge Wechsler and his colleagues rose with a reformist legislative spirit Bentham would have cheered. Seeking wisdom in the law and armed with collaboration from other disciplines, the draftsman would act as a "legislative commission, charged with construction of an ideal penal code" ${ }^{360}$ in order to induce the legislative process "to determine the contents of the penal law, the prohibitions it lays down, the excuses it admits, the sanctions it einploys, and the range of authority that it confers, by a contemporary reasoned judgment," heeding "Lord Radcliffe's counsel that 'every system of jurisprudence needs ... a constant preoccupation with the task of relating its rules and principles to the fundamental moral assumptions of the society to which it belongs." " 361

Several circumstances proved favorable to realizing this ambition. First, the undertaking was a private one, conducted by the American Law Institute under a grant from a private foundation. This allowed the draftsmen to proceed, as Wechsler observed, "free, as legislative commissions rarely are, to take account of long range values as distinguished from immediate political demands." ${ }^{362}$ Second, they were not preparing a criminal code for a particular jurisdiction where the momentum tends to favor rearranging the existing law, rendering drastic change always an uphill battle. Instead, they were preparing a criminal code that the draftsmen thought ought to be, leaving to the particular jurisdiction the decision of what to adopt and what to reject. Third, the varying and often inconsistent approaches to particular problems reflected in the criminal law of the states demanded evaluation and choice in a code that purported to be a model for all states. A restatement approach was plainly unfeasible as well as undesirable. ${ }^{363}$ Fourth, the venture had time, talent, and organization. None of the earlier codes took more than two or three years to complete, most under pressure to produce. The Model Penal Code moved at a relatively leisurely pace, taking ten years, 1952 to 1962 , to produce a final draft. Moreover, this Code was a collaborative project in a more thoroughgoing way than any of the others were. The venture conscripted scores of law professors from all over the country as Reporters and Consultants in particular areas-a striking contrast to the largely solo perfornances represented by the earlier codes. Also, where the earlier codifiers had only a few judges and prosecutors to whom to submit their drafts, the Model Penal Code had the benefit of the elaborate and wellestablished system of review of the American Law Institute. ${ }^{364}$ Finally, and probably of decisive importance, the work was led by Professor Wechsler

359. Wechsler, A Thoughtful Code of Substantive Law, 45 J. CrIM. L.C. \& P.S. 524, 526 (1955).

360. Id. at 525 .

361. Wechsler, The Model Penal Code and the Codification of American Criminal Law, in CRIMB, CRImInology AND Public Policy 419, 424-25 (R. Hood ed. 1976).

362. Wechsler, supra note 359 , at 525.

363. Wechsler, supra note 361 , at $420-21$.

364. Id. at 421 . 
who, for over a decade, had pioneered legislative rethinking of the substantive criminal law ${ }^{365}$ and who combined some of the best qualities of his predecessors-Macaulay's perspicuity and insight, Stephen's mastery of the subject matter, and Bentham's reformist dedication.

One important circumstance did not favor the Code's reformist ambitions: the ground had not been prepared by treatise writers. As Wechsler observed, "[n]o Williston or Wigmore has undertaken to chart the contours of the subject, ordering its doctrines, rules and practice in the light of underlying policies and bringing critical intelligence to bear upon the whole." 360 We may forgive Wechsler for failing to note that in one important area this task had been done-by his own and Professor Michael's classic two-part article on the Rationale of the Law of Homicide. ${ }^{307}$ Still, the great bulk of the subject had not been rethought in this way and the labors of Wechsler and his colleagues had to imclude the preparation of "rationales" of the whole of the law of crimes as part of the drafting of the Code. While this was an additional burden to the draftsmen, it resulted in a unique benefit to the field of criminal law. The extensive commentary to the thirteen tentative drafts of the Model Penal Code, far more probing, comprehensive, and integrating in analysis than the more narrowly focused supporting commentary of the earlier codes, furnished a text that revitalized criminal law scholarship, provided a new starting point for writing in the field and profoundly influenced the materials and direction of criminal law study in American law schools.

The Code itself was stunningly successful in accomplishing the comprehensive rethinking of the criminal law that Wechsler and his colleagues sought. An adequate demonstration of this assertion is beyond the scope of an article devoted to Wechsler's predecessors, but a few comments on the subject may properly serve to conclude it.

The Code, despite its reformist spirit, is in no sense an anti-establishment document. It takes the institutions of the criminal law within society as given, with none of the radical critique reflected in Livingston's Code. Society needs a system of pumishment to protect it against major harms, and it needs the criminal law to order and control the use of public force against individuals in the process of administering the system of punishment. ${ }^{368}$ The Code's ideology is the conventional one, which Wechsler described as a "moral sentiment," that so much being "at stake for the community and the individual, care has to be taken to make law as rational and just as law can be." 800

Rationality for Wechsler and his colleagues meant that prevailing law must be thoroughly re-examined for flaws and gaps, measured by an instru-

365. J. Michael \& H. Wechsler, Criminal LaW and its administration (1940); Wechsler \& Michael, A Rationale of the Law of Homicide (pts. 1 \& 2), 37 Colum. L. Riv. 701, 1261 (1937). (1952).

366. Wechsler, The Challenge of a Model Penal Code, 65 Harv. L. Rrv. 1097, 1098

367. Wechsler \& Michael, supra note 365 .

368. Wechsler, supra note 366 , at 1098.

369. Wechsler, supra note 361 , at 424 . 
mentalist standard of serving the purpose of the criminal law, and for logical solecisms. Reckless conduct is no less worthy of deterrence when harm does not occur than when it does; hence the Code creates a general crime of recklessly endangering another person. ${ }^{370}$ Whether a mistake is factual or legal is beside the point; the point is whether the mistake does or does not negative the mental element in the definition of the crime. ${ }^{371}$ Drawing the line between attempt and preparation at the point of proximity to success excludes liability for persons who have sufficiently identified themselves as dangerous; requiring a substantial step that strongly corroborates the intention gives the needed protection to innocence. ${ }^{372}$ Liability for the crime of another which is defined as requiring purpose or knowledge cannot be imposed logically unless the aider shares the required purpose or knowledge. ${ }^{373}$

Another dimension of the rationality sought by the draftsmen is their reaching toward specialized areas of expertise where logic and general policy fell short. This is illustrated in the collaboration with psychiatric experts in approaching the problem of legal insanity ${ }^{374}$ and with correctional experts in dealing with sentencing and correction. ${ }^{375}$

A third component of the rationality sought by the draftsmen is exhibited in the unremitting effort to locate and state the governing principles in areas traditionally dealt with on an ad hoc particnlarity. This confidence in the capacity to generalize legislative fornulations evokes the early codification spirit, though in the execution the formulations emerge with a degree of generality that wonld have disappointed Bentham. While in the earlier codes, causation provisions are drawn to cover particular cases, typically medical maltreatment, the Model Penal Code for the first time essays a compreliensive formulation. The provision builds on the insight that the traditional problems of "proximate causation" are basically problems of determining the cnlpability required for conviction, ${ }^{376}$ and reduces the hard questions to an inquiry whether the result is too accidental to have a just bearing on liability or degree of punishment. ${ }^{37 t}$ Perceiving that the defense of necessity has often confused cases of excuse and justification, the Code disentangles the threads, and deals separately with duress and necessity, the latter constructed on a broad lesser-evil principle (eschewed on practical grounds by Macaulay and Stephen) applicable across the board to all offenses. ${ }^{378}$ Negligence as a basis of hability runs all through the law-im particular crimes, like homicide, and in defenses, like mistake and self-defense. The Model Penal Code for the first time identified the unitary character of the concept and provided an

370. Model Penal Code $\$ 211.2$ (Proposed Off. Draft, 1962).

371. Id. \$2.04.

372. Id. \$ 5.01 .

373. Id. \$2.06.

374. Wechsler, supra note 361 , at 442; Wechsler, supra note 359 , at 529-30.

375. Wechsler, The American Law Institute: Some Observations on its Model Penal Code, 42 A.B.A.J. 321, 322 (1956).

376. Model Penal Code \$ 2.03, Comment 132 (Tent. Draft No. 4, 1955).

377. MODEL Penal Code $\$ 2.03$ (Proposed Off. Draft, 1962).

378. Modez Penal CODE $\$ 3.02$ (Proposed Off. Draft, 1962); Model Penal Code $\$ 3.02$ Comment 5 (Tent. Draft No. 8, 1958). 
integrative definition of negligence that governs in whatever guise that standard appears as the basis of liability. ${ }^{379}$

For Wechsler and his colleagues, making the law just meant at bottom that the preventive purpose of the criminal law must be sought within the constraints of the principle that punishment may not be imposed in the absence of blameworthy conduct or in disregard of the degree of blameworthiness reflected in the inental state accompanying the conduct. The standard of just blaming tends to be the conventional common-law standard, which finds blame sufficiently established "if the actor knew or should have known the facts" that give his conduct its offensive character, ${ }^{380}$ rather than an individualized standard which requires searching the ability of the particular actor to know and to conform. ${ }^{381}$ However, that conventional standard is applied with a fidelity quite unconventional in prevailing law.

Strict criminal liability is eliminated both in regulatory offenses, where only a fine or other civil penalty may be imposed without a finding of fault, 882 and in those serious offences in which it was to be found in the law under doctrinal disguises-the felony-murder and misdemeanor-manslaughter rules, the exclusion of even a reasonable mistake as a defense in such crimes as bigamy and rape, the rules that justified defensive force in certain cases solely in terms of actual, rather than reasonably apparent necessity. ${ }^{383}$ The Code's concern with justice is manifested also in the provisions dealing with justified force against the person, for here too the central value is protecting faultless conduct froin punishment. ${ }^{884}$ The Code carefully articulates the norms governing the use of such force, particularly, deadly force, in a variety of circumstances ${ }^{385}$ and, as previously noted, fornulates an innovative principle

379. Moder Penal Code $\$ 2.02(2)$ (d) (Proposed Off. Draft, 1962); Wechsler, supra note 361 , at $435-38$.

380. Wechsler, supra note 361 , at 432.

381. The Code's point of departure is that the criminal law should not

vary legal norms with the individual's capacity to meet the standards they prescribe, absent a disability that is both gross and verifiable, such as the mental disease or defect that may establish irresponsibility. The most that it is feasible to do with lesser disabilities is to accord them proper weight in sentencing.

Model Penal Code $\$ 2.09$, Comment 6 (Tent. Draft No. 10, 1960). The Codc makes some concession to the mdividual's circumstances by requiring that the reasonableness of the defendant's action, whenever that is in issue, be judged from the viewpoint of a person "in the actor's situation." E.g., id. $\$ \$ 210.3(1)(b)$ (provocation), 2.02(2)(d) (negligence) (Proposed Off. Draft, 1962). While this deliberately introduces an area of flexibility, it is plain that no wholly individualized standard was contemplated. Id. $\$ 2.02$, Comment 126 (Tent. Draft No. $4,1955)$; id. $\$ 2.09$, Comment 6 (Tent. Draft No. 10, 1960). In the interest of furthering the preventive purposes of the law the Code does not accept the position that severe emotional distress should suffice for provocation, id. $\$ 210.3$, Comment 47-48 (Tent. Draft No. 9, 1959). See also Williams, Provocation and the Reasonable Man 1954 CRIM. L. REv. 740, 741-42; that duress may rest solely on the actors inability to act otherwise because of his terror at the threat, Model Penal Code $\$ 2.09$, Comment 6-7 (Tent. Draft No. 10, 1960). Sce also G. Williams, Criminal Law: The General Part 756 (2d ed. 1961); that the right of selfdefense exists so long as the actor actually believed his life was endangered, ModBL PenaL CoDE \&3.09(2) (Proposed Off. Draft, 1962); or that negligence should require a showing that the actor was capable of taking reasonable precautions, id. $\$ 2.02(2)$ (d). See also H. L. A. HART, PUNISHMENT AND RESPONSIBILITY 154 (1968); G. WIILIAMS, supra, at 122-24.

382. Model Penal Code $\$ 2.05$ (Proposed Off. Draft, 1962).

383. Wechsler, supra note 361 , at 438 .

384. Id. at $447-49$.

385. Model Penal Code art. 3 (Proposed Off. Draft, 1962). 
of justification in the form of the lesser-evil principle. Another illustration, and one of the major contributions of the Code, is its general treatment of mens rea questions. The prevailing law had failed notoriously to distinguish varying degrees of blameworthiness reflected in the mental element of crimes. Both statutory law, when the matter was attended to at all, and case law confused the issue with moralistic epithets like wilful, malice, wantonly, corruptly, or with spongey concepts like specific and general intent. The Model Penal Code, in a remarkable tour de force of analytical precision, formulated a set of definitional tools with which the entire code of specific crimes could be fashioned. Four mental states were identified and definedpurpose, knowledge, recklessness, and negligence-and three objective elements in the definition of crimes were identified as to which the appropriate mental state had to be specified-the nature of the conduct, the attendant circumstances, and the result of the conduct. ${ }^{386}$ The contribution of this set of tools was to spothight the mens rea questions in defining crimes, to bring thought and order to the resolution of these questions and to dispel the obscurantist cloud that liung for so long on the central mens rea issues in criminal law.

Having said that justice and rationahity, in the senses described and exeinplified, constitute the Code's ideology, it is important to add that Wechsler and his colleagues proceeded with a wholly non-ideological sense of the practical. ${ }^{387}$ Capital punishment, though obviously disapproved, was left in as an option, with constraints suggested to render it less objectionable. ${ }^{388}$ Felony-murder was eliminated. But a sense of the strong pressures to retain it led the draftsmen to retain at least a shadow of its former self in the form of a presumption that a homicide in the course of a dangerous felony creates a presumption of extreme indifference to human life. ${ }^{389}$ With characteristic logic the Code treats the absence of the purpose or knowledge required for conviction of a particular crime as decisive of non-liability for that crime, whether the cause is intoxication or any other circumstance. But with uncharacteristic illogic it makes an exception for the absence of recklessness where the cause is intoxication, ${ }^{390}$ in recognition "of the political necessity of dealing specially with drunkenness." 391 Another illustration appears in confining the standard of excuse, expressed in terms of compelling circumstances irresistible to a person of reasonable firmness, to cases of physical duress of one person of another, excluding cases where a like irresistibility is produced by some other circumstance. Presumably the fear that so doing would open potentially every case to an exploration of reasonable willpower led the Code to stop short of the logic of its premise. ${ }^{392}$

386. Id. $\$ 2.02$.

387. Note Wechsler's acceptance of Professor Packer's characterization of the dominant tone of the Code "as one of principled pragmatism." Wechsler, supra note 361, at 465.

388. Model Penal Code $\$ 210.6$ (Proposed Off. Draft 1962).

389. Id. $\$ 210.2(1)(\mathrm{b})$.

390. Id. § 2.08(2).

391. Wechsler, supra note 361 , at 441.

392. S. Kadish \& M. Paulsen, Crmminal Law and its Processes 570-71 (3d ed. 1975). 
It may be that these modest dosages of accommodation to politics and practicality made the medicine of reform go down. It seems likely. What is certain is that Wechsler and his colleagues were as successful in influencing law reform as they were in producing a model code. Its formulations of entrapment and obscenity affected the course of constitutional adjudication and its treatment of the defense of legal imsanity has been adopted by almost every United States court of appeals. ${ }^{393}$ More significantly the Code stimulated a movement for legislative criminal law reform of unprecedented scope. ${ }^{394}$ The latest Annual Report of the American Law Institute reveals that over thirty states have adopted revised criminal codes since the Model Penal Code started reporting its drafts; six states and Congress have revisions completed awaiting enactinent; and three states have revisions under way. ${ }^{396}$ In very few instances has any jurisdiction adopted the Code substantially whole. But in virtually no case has the revision escaped the impact of the Code's formulations. As a result the Model Penal Code has by now permeated and transformed the substantive criminal law of the country. None of the codes we have considered, including Field's, had a greater influence. None deserved it more. 